\title{
WITH NO DELIBERATE SPEED: THE SEGREGATION OF ROMA CHILDREN IN EUROPE
}

\author{
ANTONIA ELIASON * \\ TABLE OF CONTENTS
}

INTRODUCTION 192

I. THE ROMA IN EUROPE. 193

II. CRITICAL RACE THEORY AND DISCRIMINATION AGAINST THE ROMA.

A. An Overview of Critical Race Theory. 200

B. Critical Race Theory and the Segregation of Roma Children ............. 205

III. EU AND NATIONAL ANTI-DISCRIMINATION LAWS AND

JURISPRUDENCE

A. The Race Equality Directive ........................................................... 212

B. Data Privacy

C. The European Court of Justice and the Race Equality Directive 219

D. The Jurisprudence of the European Court of Human Rights on the Segregation of Roma Children ....................................................... 226

E. National Anti-Discrimination Measures: The Case of Hungary .......... 232

IV. THE PATH FORWARD - SUGGESTIONS FOR A MORE EFFECTIVE MEANS OF ADDRESSING ROMA SEGREGATION IN EUROPE .... 235 CONCLUSION. 240

"Without education, you're not going anywhere in this world."

— Malcolm X

"Much of one's inability to know racial discrimination when one sees it results from a failure to recognize that racism is both a crime and a disease. This failure is compounded by a reluctance to admit that the illness of racism infects almost everyone. Acknowledging and understanding the

Copyright @ 2017 Antonia Eliason

* Antonia Eliason is an Assistant Professor at the University of Mississippi School of Law. She would like to thank the faculty writing groups at the University of Mississippi School of Law for helpful comments throughout the process, and particularly Jack W. Nowlin for organizing the writing groups. She would also like extend special thanks to Mathias Möschel for providing much inspiration and for his insights on Roma rights and critical race theory. Research was partly funded by a summer research grant from the University of Mississippi School of Law. 
malignancy are prerequisites to the discovery of an appropriate cure. But the diagnosis is difficult, because our own contamination with the very illness for which a cure is sought impairs our comprehension of the disorder."

- Charles R. Lawrence III, The Id, the Ego, and Equal Protection: Reckoning with Unconscious Racism, 39 STAN. L. REV. 317 19861987, 321.

\section{INTRODUCTION}

Since its formal establishment in 1993, the European Union ("EU") has built a reputation as an upholder of human rights, distancing itself from the racism that nearly destroyed the continent in the 1930s and 40s. In today's Europe, however, racism is in fact still alive and well. In particular, the Roma, Europe's largest minority, continue to face shocking levels of discrimination.

The Roma have been discriminated against throughout their history. In Central and Eastern Europe as well as in Western Europe, Roma are discriminated against in all facets of life, including in education, employment, and health care. This discrimination is most pronounced in Central and Eastern Europe due to the large Roma minority in many of the countries in the region. Some of the most intense discrimination involves Roma children who are frequently segregated from non-Roma students in schools throughout Central and Eastern Europe. While not legally institutionalized, the segregation of Roma children is comparable to that experienced by African American children in the United States throughout the 1950s and 60s.

This article focuses on the failure of anti-discrimination measures, both at the national and at the EU level, to substantively reduce discrimination against Roma children in education. Critical Race Theory ("CRT") provides the necessary context for understanding why the European Union and its individual member states continue to fail in this respect, despite numerous national and supranational measures aimed specifically at the Roma. The first section of this article provides a brief background on the Roma and the pervasive discrimination they have faced over the centuries. The second section provides an overview of CRT and discusses its relevance to the study of segregation of Roma in education, comparing the situation of the Roma in Europe with the African American population in the United States. The third section describes how existing anti-discrimination measures in the European Union and at the national level within EU Member States are inadequate as currently enforced, due to issues of systemic discrimination. Finally, the article concludes by offering several suggestions to combat segregation across Europe using existing legal tools. In particular, impact 
litigation at the local and national levels can be a critical tool in using the judicial system to effect change and must play a prominent role in addressing the segregation of Roma children.

\section{THE ROMA IN EUROPE}

Much has been written about the Roma, their origins, and the historical discrimination they have faced wherever they reside. ${ }^{1}$ This article presents an abbreviated and simplified overview in order to enable readers unfamiliar with the Roma to comprehend the scope and intensity of the discrimination they face, particularly in education, employment and public health. Roma children face discrimination in the form of school segregation across much of Central and Eastern Europe.

The Roma are Europe's largest minority, with an estimated population between ten and twelve million throughout greater Europe, ${ }^{2}$ and over six million in the European Union alone. ${ }^{3}$ Around seventy percent of the total European Roma population is concentrated in Central and Southeastern Europe. ${ }^{4}$ The Roma population is estimated at roughly ten percent of the total population in Bulgaria, nearly nine percent in Romania, nine percent in Slovakia and seven and one-half percent in Hungary. ${ }^{5}$ Accurate population data is difficult to obtain in large part because of reluctance of Roma to selfidentify for fear of repercussions; the number of individuals who selfidentify as Roma is far lower than official estimates.

Originally from India, the Roma migrated westward to Europe somewhere between 500 and 1000 A.D., reaching Europe around the thirteenth century. ${ }^{6}$ From the moment they arrived in Europe, the Roma were viewed with suspicion by native populations. Many Roma were enslaved in

1. See generally, e.g., Zoltan BARAny, The EASt European Gypsies: Regime Change, MARGINALITY, AND ETHNOPOLITICS (2002); KonRAD BERCOVICI, THE STORY OF THE GyPSIES (1928); DAVID M. Crowe, A History OF THE GyPSIES OF EASTERn EuROPE AND Russia (2d ed. 2007); ANGUS FRASER, THE GYPSIES (2d ed. 1995).

2. Report on the Implementation of the EU Framework for National Roma Integration Strategies, at 12, COM (2014) 209 final (Apr. 2, 2014).

3. Niall Crowley et Al., EURopean Parliament, EMPOWERMENT OF ROMA WOMEN Within THE EUROPEAN FRAMEWORK OF NATIONAL ROMA INCLUSION STRATEGIES 15 (2013).

4. Gerison LANSDOWn, UNICEF, THE Right OF ROMA CHILDREN TO EDUCATION: Position PAPER 15 (2011). A 2011 UNICEF position paper estimated the population at a relatively conservative ten million. Id. The Council of Europe estimates the population at six to sixteen million in all of Europe based on population data from July 2012. COUNCIL OF EUROPE, ESTIMATES AND OFFICIAL NuMBERS OF ROMA IN EUROPE (2012), http://www.coe.int/en/web/portal/roma [https://perma.cc/PG34-8BKM]. The number of officially self-identified Roma in contrast is under two million. Id.

5. ESTIMATES AND OFFICIAL NUMBERS OF ROMA IN EUROPE, supra note 4.

6. Helen O’Nions, MinORity Rights Protection in InTERnAtional LAw: THE Roma of EUROPE 3 (2007). 
what is today's Romania beginning in the thirteenth or fourteenth century and some remained enslaved until the mid-nineteenth century. ${ }^{7}$ In many European countries, laws were passed in the fifteenth and sixteenth centuries expelling the Roma; in several countries, Roma were sentenced to death if found.$^{8}$

The Roma were historically nomadic, working as metalworkers, horse breeders, horse trainers, musicians and in other traditional skilled occupations. ${ }^{9}$ Today, most are no longer itinerant, although the stereotype of the nomadic wanderer lingers in mainstream consciousness. ${ }^{10}$ In understanding their historical position in Europe, scholars have argued that the Roma are best viewed as pariah people. ${ }^{11}$ The great sociologist Max Weber famously defined the situation of pariah people as one where "the people in question have totally lost their residential anchorage and hence are completely occupied economically in meeting [the] demands of other settled peoples - the gypsies, for instance, or, in another manner, the Jews of the Middle Ages." 12 As pariah people, the absence of residential anchorage, as described by Weber, has often left the Roma vulnerable to persecution and reliant on the goodwill of the populations around them. ${ }^{13}$ István Pogány argues that this lack of residential anchorage has also contributed to the Roma's general failure to develop effective forms of political organizations. ${ }^{14}$ Pogány further argues that contrary to Weber's thesis, which was based on the idea of ritual separation often maintained and enforced by the pariah peoples themselves, modern separation of Roma from non-Roma is largely a result of anti-Romaism in Central and Eastern European countries that has replaced the ritual separation Weber originally identified. ${ }^{15}$

7. See Elena Marushiakova \& Vesselin Popov, Gypsy Slavery in Wallachia and Moldavia, in NATIONALISMS TODAY 89-123 (Tomasz Kamusella \& Krzysztof Jaskułowski eds., 2009).

8. Donald Kenrick, Historical Dictionary of THE GyPSIES (Romanies) xx-xxii (Jon Woronoff ed., 2d ed. 2007).

9. István Pogány, Pariah Peoples: Roma and the Multiple Failures of Law in Central and Eastern Europe, 21 SoC. \& LEGAL STUD. 375, 378 (2012).

10. See Nicolae Gheorghe, Choices to be Made and Prices to be Paid: Potential Roles and Consequences in Roma Activism and Policy-Making, in From VictimHOod TO CitizenshiP: THE PATH OF ROMA INTEGRATION: A DEBATE 41, 73 (Will Guy ed. 2013) (arguing that it is not acceptable to use the mythology of the nomadic Roma to "promote images of the Roma as 'eternal nomads', 'children of the wind', 'people without a state', or 'stateless, uprooted, true Europeans"” since most Roma are settled and are citizens of their respective countries.

11. See Pogány, supra note 9 , at 379 .

12. MAX Weber, The Religion OF India 13 (1958), quoted in Pogány, supra note 9, at 377.

13. Pogány, supra note 9 , at 379 .

14. Id.

15. Id. at 389 . 
As a result of their wanderings, the Roma borrowed certain elements from the societies around them while retaining their distinct cultural identity. Among the cultural acquisitions were religious beliefs and language. This has resulted in a European Roma minority that is far from monolithic; the Roma's fragmentation often seems to override their commonalities, making a unified Roma civil rights movement difficult to achieve. For instance, Romani, the Roma language, is only spoken by a minority of Roma in Central Europe, ${ }^{16}$ while a majority continues to speak it in Southeastern Europe. $^{17}$

The Roma are a physically visible racial minority throughout much of Europe. In Southeastern Europe, however, linguistic differences rather than differences in skin color most distinguish the Roma from non-Roma. ${ }^{18}$ This combination of race and ethnicity requires a nuanced approach to understanding the place of Roma in European society. As Lilla Farkas writes,

Treating Roma simply as a racial minority on account of their skin colour would deny their historical presence in and ties to Member States, and with this, their protection as an ethnic minority. Conversely, treating them only as an ethnic minority would deny protection on account of their skin colour, which distinguishes them from the majority of ethnic minorities indigenous in Member States and which is a characteristic that may exaggerate the extent of discrimination they suffer. ${ }^{19}$

The distinction between racial and ethnic identities is discussed in greater detail below. It is the Roma's racial identity, however, that has most profoundly influenced the level of discrimination they face in Central and Eastern Europe.

A high rate of illiteracy - both at present and historically - stands out among the challenges facing the Roma and has directly affected the group's educational achievement. Illiteracy has had significant implications both in the contemporary employment arena as well as in the creation of a unified Roma identity. Literacy is a requirement for most contemporary jobs. Additionally, as a traditionally non-literate minority, the Roma have never shaped historical narratives, unlike societies with written cultures that have left records of their experiences and accomplishments. ${ }^{20}$ As a result, where

16. Martin Kovats, Integration and the Politicisation of Roma Identity, in FROM VICTIMHOOD TO CITIZENSHIP, supra note 10, at 108.

17. Dieter W. Halwachs, Affiliation, Varieties, Speakers, in RomANI IN EUROPE 5 (2003).

18. Interview with Tefik Mahmut, European Roma Rights Centre, in Budapest, Hungary (June 16, 2015).

19. Lilla FARKAS, EUROPEAN COMMISSION, SEGREGATION OF ROMA CHILDREN IN EDUCATION: ADDRESSING Structural DisCRIMINATION THROUGH THE RACE EQUALITY DiRECTIVE 19 (2007).

20. See András Bíró, The Price of Roma Integration, in FrOM VICTIMHOOD TO CITIZENSHIP, supra note 10 , at 16 . 
oral traditions have been lost, the Roma are left only with non-Roma versions of their identity; versions that speak of thieves, fortune tellers, baby snatching, and other negative stereotypes. Thus, illiteracy has impaired the Roma's efforts to obtain permanent employment and has left little historical record to facilitate the creation of a modern Roma identity.

One of the most pressing challenges for the Roma in contemporary society is an extremely high rate of unemployment, due largely to society's unwillingness to hire Roma employees, but also in part to the Roma's lack of educational achievement in an economic milieu that increasingly requires educational certifications. In Slovakia and the Czech Republic, rates of Roma unemployment have been estimated as high as eighty percent ${ }^{21}$ (although this does not take into account the grey economy, where many Roma work unofficially). Similarly, "in Bulgaria, between sixty and eighty percent of the [Roma population] suffers permanent unemployment," and nearly eighty percent of Roma in Bulgaria and Romania live on less than five dollars per day. ${ }^{22}$ Before the collapse of Communism in 1989-1990, unemployment was virtually nonexistent in Central and Eastern Europe, because governments mandated employment for all citizens. ${ }^{23}$ However, since the collapse of Communism, Roma unemployment has increasedwith a tendency to be longer term - and many Roma have been permanently excluded from the labor market. ${ }^{24}$

Public health is another area of concern for the Roma. The Roma have faced a variety of health problems due to their social exclusion. The average Roma life span is nearly ten years less than the majority populations in Central and Eastern Europe, and the Roma experience higher rates of infant mortality, malnutrition and disease. ${ }^{25}$ In some areas, Roma life expectancy may be as much as twenty years less than the majority population. ${ }^{26}$ As a result of poverty, the Roma experience higher rates of disease due in part to poor diet and stress. ${ }^{27}$ Additionally, high illiteracy rates contribute to the

21. MARK Bell, RACISM AND EQUALITY IN THE EUROPEAN UNiON 90 (2008).

22. James A. Goldston, The Struggle for Roma Rights: Arguments that Have Worked, 32 HuM. RTS. Q. 311, 314 (2010).

23. See Orsolya Farkas, The Roma and Their Integration to the Labour Market: A Comparison Between Hungary and Slovakia, 3 EUR. Y.B. MiNORITY IsSUES 325, 327 (2003-2004).

24. See Niall O'Higgins \& Andrey Ivanov, Education and Employment Opportunities for the Roma, 48 COMP. ECON. STUD. 6, 10 (2006).

25. Goldston, supra note 22, at 314.

26. Matrix, Roma Health Report: Health Status of the Roma Population. Data Collection IN THE Member States of THE European Union 37 (2014), http://ec.europa.eu/ health/social_determinants/docs/2014_roma_health_report_en.pdf [https://perma.cc/AP2C-TQZD].

27. Id. at 49. 
Roma's underuse of universally available health services, particularly in countries where the Roma are migrants. ${ }^{28}$

The Roma are routinely victims of anti-Roma hate crimes in both Western and Eastern Europe. The European Court of Human Rights ("ECtHR") has heard numerous cases involving attacks against Roma by private individuals; in several situations, Roma houses were burnt by local populations. ${ }^{29}$ The Roma have also been the frequent target of police brutality. ${ }^{30}$ Across Europe, mob justice and individual hate crimes have left the Roma beaten, tortured and killed simply for being Roma. ${ }^{31}$

Beyond these main areas of concern, Roma women face additional challenges. Roma women have been particularly disadvantaged in the areas of employment, health and education. ${ }^{32}$ These disadvantages result in knockon adverse effects for the children of Roma women, who experience deepened social exclusion as a result of the challenges their mothers face. ${ }^{33}$

This article focuses specifically on the discrimination Roma children face in education; particularly the various forms of segregation present in Central and Eastern Europe. Three million Roma children attend schools across the European Union, and many face structural discrimination in the

\section{Id. at 58 .}

29. See, e.g., Angelova and Iliev v. Bulgaria, 533 Eur. Ct. H.R. 1 (2007); Gergely v. Romania, App. No. 57885/00, Eur. Ct. H.R. 1 (2007); Kalanyos and Others v. Romania, App. No. 57884/00, Eur. Ct. H.R. 1 (2007).

30. See, e.g., Guerdner and Others v. France, App. No. 68780/10, 426 Eur. Ct. H.R. 1 (2014); Nachova and Others v. Bulgaria, App. Nos. 43577/98 \& 43579/98, Eur. Ct. H.R. 1 (2005).

31. In July 2015, an Italian court found six people guilty of hate crimes against Roma for an attack on an informal Roma settlement by a mob intent on punishing the Roma community for the alleged rape of a non-Roma girl. As part of the attack, the mob set fire to the settlement. Historic Criminal Conviction for a Violent Assault to a Roma Camp in Italy, EuROPEAn RoMA Rights CENTRE (Jul. 17, 2015), http://www.errc.org/article/historic-criminal-conviction-for-a-violent-assault-to-a-roma-camp-initaly/4385 [https://perma.cc/3WJ4-BABU]. This is a rare case of the perpetrators of anti-Roma violence being brought to justice. In another case, in 2012, an off-duty police officer shot and killed three Roma and seriously injured two others in a shooting spree in Slovakia, but was only sentenced to nine years in prison with no racial motivation considered despite his statements that he was going to "solve the Roma problem." Year on from Roma Deaths, ERRC Highlights Low Sentence for Mass Murdered in Slovakia, EUROPEAN ROMA RIGHTS CENTRE (June 17, 2013), http://www.errc.org/article/one-year-on-from-romadeaths-errc-highlights-low-sentence-for-mass-murderer-in-slovakia/4150 [https://perma.cc/W26S-SJD A].

32. Kristina Koldinská, EU Non-Discrimination Law and Policies in Reaction to Intersectional Discrimination Against Roma Women in Central and Eastern Europe, in EUROPEAN UNION NONDISCRIMINATION LAW AND INTERSECTIONALITY: INVESTIGATING THE TRIANGLE OF RACIAL, GENDER AND DisABILITY DisCRIMINATION 241, 242-43 (Dagmar Schiek \& Anna Lawson eds., 2011). Koldinská notes that where mothers bear responsibility for raising children, if they themselves lack advanced education and live with their children in a socially excluded environment, the social exclusion is more likely to pass to the next generation. $I d$. at 243.

33. See, e.g., BELL, supra note 21, at 116 (noting that the Roma infant mortality rate in Romania is four times the national average). 
form of segregation and institutional discrimination. ${ }^{34}$ As a result, many fail to complete primary education and many more fail to complete secondary school. ${ }^{35}$ In some regions of Europe, only thirty to forty percent of Roma children regularly attend school, and up to ninety percent of adults are illiterate. ${ }^{36}$ Education is a key predictor of future success and without school integration, Roma children will remain disadvantaged.

Segregation is shockingly widespread and overt. Three main types of school-based segregation have arisen: intra-school segregation, where Roma students are taught inferior curricula in separate classes within the same school; intra-class segregation, where Roma students are instructed under different curricular standards within the same class as non-Roma students; and inter-school segregation, where Roma and non-Roma children attend different schools based on either residential segregation, poorlydesigned testing that leads to placement in remedial schools, or the creation of private schools that require tuition or testing for admission to the disadvantage of Roma children. ${ }^{37}$ Inter-school segregation is widespread; particularly in Bulgaria where many Roma children attend geographically segregated schools, and in Slovakia and the Czech Republic where Roma children are deemed mentally challenged and sent to remedial schools. ${ }^{38} \mathrm{~A}$ fourth type of segregation, individual segregation, or forced home schooling, often occurs, albeit with less frequency. ${ }^{39}$

Jack Greenberg, a renowned civil rights litigator, has noted that unlike in the United States, where segregation prior to Brown v. Board of Education was required by law, segregation in Eastern Europe has resulted from a mix of local official policies (state action) and informal forces, like housing policies ("de facto" segregation). ${ }^{40}$ This key difference shapes the remedies and responses available to address segregation.

Segregation of Roma in European schools is a result of intentional policies and passive disregard for the obstacles faced by Roma children. These obstacles include cultural differences, inefficiencies within school

34. FARKAS, supra note 19 , at 4 .

35. Goldston, supra note 22, at 314.

36. O'NiONS, supra note 6, at 131-32.

37. FARKAS, supra note 19, at 10; see also Jack Greenberg, Report on Roma Education Today: From Slavery to Segregation and Beyond, 110 COLUM. L. REV. 919, 935-36 (2010).

38. Marius Taba \& Andrew Ryder, Institutional Responses to Segregation: The Role of Governments and Non-Governmental Organizations, in TEN YEARS AFTER: A HISTORY OF ROMA SCHOOL DESEGREGATION IN CENTRAL AND EASTERN EuROPE 7, 9-10 (Iulius Rostas ed., 2012).

39. FARKAS, supra note 19 , at 10.

40. Greenberg, supra note 37 , at 935 . 
systems and discrimination by teachers and fellow students. ${ }^{41}$ Roma children who speak Romani at home often face linguistic challenges adapting to schools where instruction is in another language. ${ }^{42}$ Roma children may also lack social skills as a result of extreme poverty. ${ }^{43}$ In many cases, parents lack the educational skills to support their children's schooling, and children subsequently must leave school at a young age to become economically productive. ${ }^{44}$ Many Roma children lack birth certificates for a variety of reasons, including parental illiteracy and unawareness of government requirements, parental mistrust of government registration, and hospitals' unwillingness to assist Roma citizens. Without birth certificates, Roma children cannot register for school. ${ }^{45}$ Because preschool is not free in many countries, Roma children whose parents lack the means to pay for preschool enter primary school at a disadvantage compared to their white majority peers. ${ }^{46}$ Together, these cultural disadvantages-when coupled with systemic discrimination and an unwillingness on the part of school systems and governments to integrate and provide the resources necessary to improve Roma access to education - have resulted in widespread segregation and low levels of educational achievement for Roma children.

The discrimination by peers and teachers experienced by Roma children contributes to their segregation and lack of academic success; in fact, some Roma families prefer segregated schools as a means of avoiding daily discrimination even where educational quality is significantly inferior. ${ }^{47}$ Even in integrated school districts, schools often take an assimilationist approach to educating Roma students, ${ }^{48}$ believing that Roma students must abandon their Roma identity and become like the white majority to be successful. This attitude devalues Roma identity and contributes to feelings of inferiority among Roma students.

While the brief overview above omits many complexities concerning the Roma and the discrimination they face, it should be clear that they are routinely victimized and discriminated against on stereotypical bases. This discrimination ultimately creates a vicious cycle of poverty, lack of

41. O’NiOnS, supra note 6, at 146; see also Sina van den Bogaert, Roma Segregation in Education: Direct or Indirect Discrimination?: An Analysis of the Parallels and Differences Between Council Directive 2000/43/EC and Recent ECtHR Case Law on Roma Educational Matters, 71 ZEITSCHRIFT FÜR AUSLÄNDISCHES ÖFFENTLICHES RECHT UND VÖLKERRECHT 721, 721 (2011).

42. O’NiONS, supra note 6, at 146.

43. Id. at 148 .

44. See id. at 149.

45. UNICEF, supra note 4 , at 18 .

46. Id. at $17-18$.

47. Id. at 18 .

48. O'NiONS, supra note 6, at 132. 
educational achievement, health problems and criminal activity. As Mathias Möschel writes: "The example of the Roma is particularly interesting because it stands in stark contrast to the image of Europe having overcome its overtly racist past. At the same time, the case of the Roma is so obvious that even lawyers cannot deny the role of law . . ."49 It is with this juxtaposition in mind that this article examines the Roma's segregation and the failures of EU and national measures to eliminate it. Education is critical to Roma success, and so long as Roma children lack access to education on equal terms to their majority peers, the chances of a meaningful decline in discrimination against Roma are small.

\section{CRITICAL RACE THEORY AND DISCRIMINATION AGAINST THE ROMA}

To understand how discrimination against the Roma has continued unabated despite legal measures enacted to prevent it, it is necessary to look to critical race theory. The following discussion provides an overview of critical race theory and explains why it has yet to be widely applied in Europe. The discussion then undertakes a comparative analysis of the United States and Europe in order to explain why critical race theory may be applied to the Roma's situation in Europe.

\section{A. An Overview of Critical Race Theory}

Critical race theory offers a framework for understanding discrimination against the Roma generally, and more specifically, the persistent segregation of Roma children. As a movement, critical race theory is quite new, originating in the United States during the late 1970s. ${ }^{50}$ Over the last few years, the theory has been applied to racism in Europe, but only to a limited extent.

Critical race theory encompasses many different propositions. Its core principles include the following:

1) Racism is normal rather than aberrational;

2) Racism advances the interests of both white elites and the white working class, both of which lack incentives to eliminate it; and

3) Races are social constructs rather than genetic reality. ${ }^{51}$

\footnotetext{
49. Mathias Möschel, Law, LaWyers and Race: Critical Race Theory From the United STATES TO EUROPE 145 (2014).

50. Richard Delgado \& Jean Stefancic, Critical Race Theory: An Introduction 4 (2d ed. 2012).

51. Id. at $7-8$.
} 
Critical race theory recognizes that racism is engrained in the structure of society. Where power structures are based on the supremacy of white majorities, minorities such as African Americans or Roma have little opportunity to overcome negative perceptions against them. This idea of structural determinism - an important aspect of critical race theorysuggests that the system itself is set up in a manner that makes redressing injustices against minorities more difficult, if not impossible. ${ }^{52}$ As Charles R. Lawrence III writes, "[b]ecause racism is so deeply ingrained in our culture[s], it is likely to be transmitted by tacit understandings: Even if a child is not told that blacks are inferior, he learns that lesson by observing the behavior of others. ${ }^{, 53}$ In essence, as a result of systemic structural racism, minorities internalize their perceived inferiority and view themselves in a deprecatory fashion. ${ }^{54}$

Interest convergence is another central concept of critical race theory. Because white majorities dictate legal and political decision making, they have little incentive to take action and ameliorate the situation of minorities. Such actions would reap little to no corresponding benefit for the white majorities. Derrick A. Bell - a pioneering scholar of critical race theorydiscusses interest convergence in his seminal article on Brown v. Board of Education. Bell argues that "[t]he interest of blacks in achieving racial equality will be accommodated only when it converges with the interests of whites." 55 Post-Brown, Bell argues, the Supreme Court's segregation decisions reflected a growing divergence between the interests of whites and blacks, and undermined Brown's hope and promise. ${ }^{56}$ As Bell recognizes, anti-defiance measures intended to force a racial balance, like bussing, failed to guarantee a better education for black children. ${ }^{57}$ They also failed to address other discrimination issues. For instance, school suspensions or expulsions occur at much higher rates for black students than for white students. $^{58}$

One of the key criticisms by critical race theorists against antidiscrimination laws is that these laws are, to quote Alan David Freeman,

52. Id. at 31 .

53. Charles R. Lawrence III, The Id, the Ego, and Equal Protection: Reckoning with Unconscious Racism, 39 STAN. L. Rev. 317, 323 (1987).

54. O'Nions, supra note 6, at 29.

55. Derrick A. Bell, Jr., Brown v. Board of Education and the Interest-Convergence Dilemma, 93 HARV. L. REV. 518, 523 (1980).

56. Id. at 528 .

57. Id. at 530-31.

58. Id. at 531 . 
"hopelessly embedded in the perpetrator perspective."59 Rather than focusing on the condition of victims, antidiscrimination laws merely focus on outlawing and neutralizing the effects of specific violations. ${ }^{60}$ This results in overemphasis on the perpetrator's intent, rather than the effect on the victim. Regardless of the perpetrator's intent, the victim's experience is the most instrumental indicator of discrimination.

In contrast to Europe, where collective rights often supersede individual rights, the American legal system is founded on principles of individual rights. In theoretical terms, this means that formal equality predominates over substantive equality in American jurisprudence, since the focus is on the individual. The Aristotelian idea of formal equality, or equal treatment, holds that a person has a right to be treated on equal terms to other persons similarly situated. ${ }^{61}$ Formal equality focuses on the individual, who is central in both enforcement procedures and remedies. Individuals are also primarily responsible for bringing claims of discrimination before courts. ${ }^{62}$ In contrast, substantive equality, or equality-in-fact, is less individually-focused, and instead considers the effects of discrimination on members of a particular group. Substantive equality aims to compensate classes of individuals for the disadvantages and inequalities they have experienced. ${ }^{63}$ This approach eschews the individualistic focus of formal equality, and instead emphasizes the "collective experiences of inequality." 64 Whereas formal equality requires equal treatment for all-as illustrated by prohibitions of direct discrimination ${ }^{65}$ - substantive equality may require unequal treatment in order to offset social disadvantages and achieve equality. ${ }^{66}$ Affirmative action - or positive action, as known in Europe-is an application of the principles underlying substantive equality.

Two additional subcategories of substantive equality have been recognized - equality of opportunity and equality of results. ${ }^{67}$ Equality of opportunity "is not concerned with the end result, but only aims to make the starting point equal for all;" as such, equality of opportunity may call for

59. Alan David Freeman, Legitimizing Racial Discrimination Through Antidiscrimination Law: A Critical Review of Supreme Court Doctrine, 62 MINN. L. REV. 1049, 1053-54 (1978).

60. Id.

61. ERICA Howard, The EU Race DiRective: DeVeloping the Protection Against Racial DISCRIMINATION WITHIN THE EU 109 (2010).

62. Id. at 114.

63. Id. at 115.

64. BELL, supra note 21, at 32.

65. Id. at 28.

66. HOWARD, supra note 61 , at 115.

67. Id. at 117. 
unequal treatment and unequal finishing points. ${ }^{68}$ In other words, equality of opportunity aims to provide all parties with the same opportunities, even if that requires initially treating certain parties more favorably than others. Equality of results takes into account past discrimination and focuses on redistributing goods and resources more fairly. ${ }^{69}$ It differs from equality of opportunity in that it is focused on ensuring equality at the finishing point, rather than at an initial starting point. These distinctions can be difficult to define, and in applying principles of substantive equality, there are risks of ascribing immutable characteristics of group membership to individual members in a group while overlooking internal diversity. ${ }^{70}$ Nevertheless, substantive equality offers a more nuanced approach to rectifying discrimination than does formal equality, particularly where de jure segregation resulting in direct discrimination (such as pre-Brown segregation in the United States) does not exist.

In addressing segregation, the United States Supreme Court initially contemplated the application of affirmative action and adopted a more substantive, equality-based approach. In subsequent years, however, the Court has backtracked and adopted a more traditional, individual rightsbased approach grounded in formal equality. This, as Alan David Freeman writes, is the era of rationalization, where the pretense that is associated with the color-blind theory of racial discrimination is "that but for an occasional aberrational practice, future society is already here and functioning." view, "the actual conditions of racial powerlessness, poverty, and unemployment can be regarded as no more than conditions-not as racial discrimination."72 Rationalization means treating these conditions "as historical accidents or products of a malevolent fate, or, even worse, . . . blaming the victims as inadequate to function in the good society." 73 Freeman's view on color-blindness is instrumental in understanding critical race theory and the failure of European antidiscrimination measures to reduce segregation and improve the situation of Roma children in education.

Critical race theory stands in sharp contrast to the belief in colorblindness shared by many liberals ${ }^{74}$ and embraced by the United States Supreme Court, which has used color blindness to "slowly but surely dismantle the use of race and race-conscious remedies by the legislator and

\footnotetext{
68. Id.

69. Id. at 120

70. See BELL, supra note 21, at 36-40.

71. Freeman, supra note 59, at 1103.

72. Id.

73. Id.

74. See DELGADO \& STEFANCIC, supra note 50, at 26.
} 
public authorities." 75 Critical race theory, on the other hand, holds that merely acting as if race does not matter, or indeed acting as if taking into account race to rectify past injustices is itself a wrong, will not eliminate racism or ameliorate the situation of minorities. Critical race theorists instead believe that "[o]nly aggressive color-conscious efforts to change the way things are will do much to ameliorate misery." permeates European discourse on discrimination, and critical race theory offers a necessary counterpoint to this view.

Critical race theory is primarily an American theory, and the lack of scholarship addressing the theory in Europe is perplexing; particularly given the growing racial tensions in Europe towards both migrants and Roma, and the strong focus among both scholars and policy makers on antidiscrimination principles. Mathias Möschel-one of the few European scholars to grapple directly with the application of critical race theory to European law - has argued that since Europe does not have the same focus on liberal individual rights as the United States, "[critical race theory's] heavy critique of the liberal individual rights model was 'doomed' from the beginning by Europe's different tradition, leaving it without any bite."77 Additionally, Möschel argues that because continental European law operates according to a "systematic, scientific, top to bottom view," critical race theory, which offers a more emotive, bottom-up perspective of the law, has faced particular challenges in entering into European legal analysis. ${ }^{78}$ As Möschel notes, "one of the fundamental points European legal scholarship can and must learn from [critical race theory] is that law is not a neutral science." 79

This aspect of the civil law jurisdictions that form the core of continental Europe's legal systems - that law is viewed as a neutral science-is worth emphasizing. In most European countries, legal systems are constructed under the presumption that law is itself neutral. Law is elevated to the status of a scientific principle, and judges in many European countries are even prohibited from referring to scholarly works in their decisions. ${ }^{80}$ Thus, academic scholarship and legal practice are separated by different perceptions of the law and European legal scholars respond by focusing on abstract theoretical frameworks rather than practical

\footnotetext{
75. MöSCHEL, supra note 49 , at 47.

76. Delgado \& STEFANCIC, supra note 50, at 27 .

77. Mathias Möschel, Color Blindness or Total Blindness? The Absence of Critical Race Theory in Europe, 9 RUTGERS RACE \& L. REv. 57, 80 (2007).

78. Id. at 94-95.

79. Id. at 106

80. MösCHEL, supra note 49, at 108-09.
} 
applications of the law. In this environment, theories such as critical race theory find less purchase because they are critical of systemic structures and judicial decisions.

There is a third element that has prevented critical race theory from gaining a foothold in Europe - the difference between European and American perceptions of race. European perspectives on race and racism are indelibly linked to the Holocaust and the racially-focused laws and actions propagated by the Nazi regime to eliminate the Jewish population. ${ }^{81}$ These historical ties have resulted in a profound reluctance among Europeans to describe anything in terms of race. Instead, Europeans have tempered discussions of race and ethnicity by using terms such as prejudice and xenophobia. ${ }^{82}$ While American anti-discrimination legislation began by focusing on racial discrimination before moving to other areas such as gender and disability, anti-discrimination legislation in Europe began by addressing gender discrimination, and only later targeted racial discrimination. ${ }^{83}$

\section{B. Critical Race Theory and the Segregation of Roma Children}

The applicability of critical race theory to the Roma's situation in Europe is best understood by comparison to the experiences of African Americans in the United States. While there are substantive differences between the two minority groups, critical race theory is not designed to speak solely to the situation of African Americans. Rather, the theory is applicable to both communities given their similar experiences of disenfranchisement amidst societies dominated by white majorities. A comparison with African Americans serves to highlight the extent of the discrimination faced by the Roma and the challenges hindering efforts to desegregate schools. In particular, identification as Roma carries with it a stigma similar to that borne by African Americans, and Roma are often described as lacking a positive identity. Schools that desegregate have experienced white flight as a result.

The approach by the United States Supreme Court in Brown v. Board of Education offers a starting point for our comparison of segregation in the United States and segregation of Roma children in Europe. Brown is one of the most important cases in American legal history, yet its implementation and long-term effects have been clouded by persistent structural racism. Desegregation post-Brown required heavy involvement by the federal government, both in enforcing the decision and in implementing legislation

\footnotetext{
81. See id. at 92 .

82. See id. at 93.

83. See id. at 92.
} 
to help give it effect. Even then, as Alan David Freeman explains, Brown's effect on black school children was more limited than anticipated:

By way of hindsight, the case stood for both more and less than a guarantee of equal educational quality. It came to stand for more insofar as its holding was quickly extended to other forms of state imposed segregation. But it stood for a great deal less insofar as black children today have neither an affirmative right to receive an integrated education nor a right to equality of resources for their schools, which, ironically, was a litigable claim under the regime of de jure segregation. ${ }^{84}$

This failure to achieve the promised equality in the aftermath of Brown provides a lesson on the limitations of legal systems in effecting substantive societal change. While laws can prohibit formal discrimination, they cannot by themselves change minds and remove centuries of ingrained racism. ${ }^{85}$

Brown's significance as a case study on the reasons underlying the continued segregation of Roma children runs beyond the decision itself. Critical race theorists and other scholars have criticized the decision and the failed efforts post-Brown to achieve equality in education despite a clear mandate to desegregate American schools. As Jack Greenberg has written on the issue of segregation of Roma children, "[s]imilarities between Roma and African American school segregation suggest consulting U.S. experience, but not uncritically adopting its remedies," since the process of desegregation in the United States "is now crippled by a near impenetrable barrier between city and suburb and a recently imposed Supreme Court prohibition of affirmative action, even when voluntarily adopted by communities." 86

The legacy of Brown, particularly re-segregation in the United States, ${ }^{87}$ highlights the difficulties of successfully maintaining school integration and illustrates the limitations of desegregation in post-Brown society. Until the 1969 Supreme Court case Alexander v. Holmes County Board of Education (which demanded that desegregation take place immediately, after years of delays and excuses), ${ }^{88}$ districts were considered desegregated so long as there was partial, rather than complete, desegregation. Thus, as a result of residential segregation, urban schools typically remained segregated. ${ }^{89}$ Alexander addressed this obstacle by requiring immediate and complete

84. Freeman, supra note 59, at 1068.

85. See HowARD, supra note 61 , at 70.

86. Greenberg, supra note 37, at 977.

87. Much scholarly attention has been given to the problem of re-segregation in the United States. See generally, e.g., Erwin Chemerinsky, The Segregation and Resegregation of American Public Education: The Courts' Role, 81 N.C. L. REV. 1597 (2003).

88. Alexander v. Holmes Cty. Bd. of Ed., 396 U.S. 19 (1969).

89. Greenberg, supra note 37 , at 984. 
desegregation. However, after the Supreme Court's holding in Milliken v. Bradley, ${ }^{90}$ courts were once again restricted in their capacity to require desegregation across school districts and desegregation efforts were stalled. ${ }^{91}$ Ultimately, the period between Alexander and Milliken allowed only five years of thorough desegregation before progress toward integration slowed and eventually began to reverse course. Today, racial integration within the United States has unraveled and re-segregation has occurred through the judicial and legislative elimination of legal and policy tools necessary to prevent de facto segregation.

Re-segregation within the United States has been propelled by an emphasis on market access that has redefined the Constitution's role in protecting individual rights. The approach increasingly taken by the United States Supreme Court in relation to the hierarchy of norms places market access above individual rights, and can be compared with similar approaches taken by legislation and case law in the European Union, which - in keeping with its origins as an economic union-has focused primarily on providing market access. Within this economic framework, as Derrick A. Bell argues, white majorities in the United States have willingly accepted a widening gap with regard to economic opportunities, but only so long as they retain priority in accessing these limited opportunities over blacks and other racial minorities. ${ }^{92}$ The same can be said for white Europeans.

White flight has plagued Central European schools where ethnic diversity is less tolerated, much like in the United States following Brown II and its requirement that schools desegregate "with all deliberate speed,"93 and particularly after Alexander. In many cases, where school districts in Central Europe have attempted to integrate and eliminate segregation between Roma and non-Roma students, non-Roma parents have either removed their children from integrated schools and placed them into private academies or moved them to different school districts altogether. ${ }^{94}$ The threshold percentage of Roma students triggering this white flight appears to be around twenty to forty percent. ${ }^{95}$ Many statements about the Roma by

90. Milliken v. Bradley, 418 U.S. 717 (1974).

91. Greenberg, supra note 37 , at 984.

92. Derrick A. Bell, Jr., After We're Gone: Prudent Speculations on America in a Postracial Epoch, in CRitical Race Theory: The CutTing Edge 2, 7-8 (Richard Delgado \& Jean Stefancic eds., 3d ed. 2013).

93. Brown v. Bd. of Educ., 349 U.S. 294, 301 (1955).

94. See Claire Schiff, Introduction: Understanding the Salience of Ethnicity in the Educational Experiences of Minority Adolescents Across Europe in MigRAnT, ROMA AND POST-COLONIAL YouTH IN EduCATION ACROSS EUROPE: BEING 'Visibly DifFERENT' 1, 9 (Julia Szalai \& Claire Schiff eds., 2014).

95. Vera Messing, Apart or Together: Motivations Behind Ethnic Segregation in Education Across 
parents and educators among the white majority echo viewpoints held by those who opposed desegregation in the United States during the 1950s and 60s. These statements blame the inadequate culture and morals of the Roma families for the failure of Roma children to succeed educationally; ${ }^{96}$ some even ascribe Roma students' academic struggles to "blood." 97 Much of the discourse on Roma children from educators emphasizes their 'otherness' as a reason for the Roma's failure to thrive in education. These statements ignore the effects of discrimination and economic deprivation on childrens' ability to learn and succeed. ${ }^{98}$

Throughout Europe, identification as Roma carries with it a stigma similar to that experienced by African Americans in the United States. ${ }^{99}$ The social consequences of this stigmatization are twofold: stigmatized Roma children are psychologically harmed by the assault on their self-respect and dignity, and the children are branded as outcasts and as inferior. ${ }^{100}$ Racial stigma is self-perpetuating. ${ }^{101}$ As a result of racial stigma, Roma children experience fewer opportunities to flourish. With fewer educational and experiential opportunities, Roma children rarely achieve success and, as Charles Lawrence writes, "the prophecy of their inferiority is fulfilled."102 Roma youth are often limited in their vocational dreams to those areas where their presence is tolerated, such as construction, and they receive little encouragement or support from their predominantly white educators. ${ }^{103}$ As a result of the stigmatization process, multi-generational poverty is frequently misconstrued as a cultural trait for which the Roma themselves are morally responsible. ${ }^{104}$

Within this framework, the continued segregation of Roma students is arguably the most prominent factor limiting the Roma's opportunities and perpetuating their cycle of poverty. Among the various forms of segregation

Europe, in Migrant, Roma AND Post-Colonial Youth IN EdUCATION ACROSS EuRope, supra note 94, at 17, 27; see also Taba \& Ryder, supra note 38, at 9.

96. Claire Schiff, Teachers' Approaches to Ethnic Minority Students through a Comparative Lens, in Migrant, Roma AND Post-COlONIAL Youth In EduCATION ACROSS EuROPE, supra note 94, at 51, 57.

97. Id. at 64; see also Taba \& Ryder, supra note 38, at 14.

98. Schiff, supra note 94 , at 3.

99. See id.

100. Lawrence, supra note 53, at 351.

101. Id.

102. Id.

103. See Julia Szalai, The Emerging 'Ethnic Ceiling': Implications of Grading on Adolescents' Education Advancement in Comparative Perspective, in Migrant, ROMA AND POST-COLONIAL YOUTH IN EDUCATION ACROSS EUROPE, supra note 94, at 67, 81-82.

104. Id. at 80 . 
in Central and Eastern Europe are "zero-grade" systems in Slovakian schools. These programs are designed to prepare children lacking in social and academic skills for participation in normal primary school classes. However, these programs often fail to provide the necessary preparation and frequently track Roma children into lower-level academic curricula. ${ }^{105}$ Another disguised form of segregation found particularly in Hungary and Romania uses existing legal protections designed to promote national minority education to keep Roma children together in classrooms; purportedly helping them overcome language barriers and attend special classes relating to their Romani ethnicity. ${ }^{106}$ In Bulgaria, schools in districts with dwindling student populations enroll Roma students from settlements up to thirty miles away to meet student enrollment requirements, without providing transportation for these students. As such, Roma children are effectively excluded from the educational system. ${ }^{107}$ In each of these examples, measures that purport to aid Roma children ultimately act as disguised forms of segregation that entrench the Roma's unfortunate status quo.

Most discussion of educational reform with regards to the Roma has focused on the integration of Roma children into majority white school systems. By itself, however, the absolute integration or assimilation of Roma children into white-dominated schools will not improve Roma education. Rather, Roma identities and differences must be valued and the culture's 'otherness' must be translated into a positive understanding of diversity. In rare circumstances where negative perceptions of the Roma have not been entrenched in the historical consciousness, the Roma have thrived. ${ }^{108}$

One frequently repeated statement regarding the Roma is that they lack characteristics capable of providing them with a positive sense of identity. In response to critics who claim the Roma lack a positive identity, we need only consider the situation of African Americans in the United States before

105. Taba \& Ryder, supra note 38, at 12; see also Messing, supra note 95, at 23.

106. Taba \& Ryder, supra note 38 , at $12-13$.

107. Id. at 13 .

108. The example of Túrkeve springs to mind. Túrkeve is a small town of about 9,000 inhabitants in eastern Hungary, where for various cultural and historical reasons, the Roma are relatively successful and unusually integrated into the community. (This is not to say that there is no anti-Roma sentiment: local non-Roma, like almost everyone you meet in Hungary, often resort to stereotypes in characterizing Roma.) There is no Roma shantytown at the outskirts of the town, and while the Roma did mostly inhabit the periphery of the town, due to existing prejudices, the level of anti-Roma sentiment never resulted in full Roma exclusion. While systemic prejudices still remain, entrenched in the very vocabulary of modern social and legal discourse, the Roma minority in the town are at least as successful as the white majority. This demonstrates the brutally insidious effects that harsh negative perceptions of Roma have over time, since there is no reason why this town should be such an anomaly in Central Europe. 
the Civil Rights Movement led to widespread embrace of African American identity. At present, Roma identity is viewed positively only in the limited realm of music and entertainment. These views are strikingly similar to white majority perceptions of African Americans in the United States prior to the Civil Rights Movement.

Many recent efforts to address segregation in European schools have focused on the integration of immigrant minority groups into national school systems. The Roma have unique socioeconomic attributes that differentiate them from other racial and ethnic minorities in Europe. They are not immigrants, and like African Americans in the United States, have experienced centuries of oppression by a white majority population. It is, in fact, indicative of the discrimination Roma face throughout Europe that most contemporary discourse on race in Europe has arisen not in response to the plight of the Roma-Europe's largest racial and ethnic minority-but in response to growing immigrant populations; a much more recent phenomenon. While the plight of immigrants is a pressing concern, it is shameful that the systematic oppression of millions of Roma has continued unabated for so long and only gained traction by way of association with a smaller-scale, but higher profile problem. Despite years of policies, discourse and laws focusing on the Roma, racism and discriminatory attitudes entrenched among the majority population have resulted in little positive change.

\section{EU AND NATIONAL ANTI-DISCRIMINATION LAWS AND JURISPRUDENCE}

EU and national anti-discrimination laws have thus far proven inadequate to eliminate segregation in European schools. Over the last fifteen years, the European Union has issued numerous policy statements, studies and pronouncements on the Roma in an effort to improve their situation. ${ }^{109}$ Apart from the European Union, the Decade of Roma Inclusion - a ten-year, multinational project between twelve EU and non-EU European nations with large Roma populations - was launched in 2005 to enhance the lives of the Roma. ${ }^{110}$ The Decade of Roma Inclusion formally ended in September 2015. Ultimately, most measures implemented by the

109. See, e.g., The Social and Economic Integration of the Roma in Europe, COM (2010) 133 final (Apr. 7, 2010); National Roma Integration Strategies: A First Step in the Implementation of the EU Framework, COM (2012) 226 final (May 21, 2012); Council Recommendation on Effective Roma Integration Measures in the Member States, 2013 O.J. (C 378) 56, 1.

110. Eben Friedman, UNDP, DeCAde of Roma InClusion Progress RePORT 6 (2015), http://www.eurasia.undp.org/content/dam/rbec/docs/DORI\%20REPORT.pdf [https://perma.cc/65QV-2 SJE]. 
European Union and the Decade of Roma Inclusion have proven ineffective in addressing discrimination against the Roma. Where there has been substantive development, albeit not necessarily as a result of policies towards the Roma, is in the realm of anti-discrimination legislation and jurisprudence. This section focuses on these legal instruments and opinions, and argues that EU anti-discrimination law - as currently enforced-is inadequate to address discrimination against the Roma. The educational segregation of Roma children has continued throughout Europe, even though it is illegal under the EU Race Directive, ECtHR case law-particularly the decisions in D.H. and Others, Sampanis, and Orsus and Others - and the International Convention on the Elimination of All Forms of Racial Discrimination ("ICERD”). Existing ECtHR jurisprudence lacks associated enforcement capabilities, and when coupled with a lack of jurisprudence in the Court of Justice of the European Union ("CJEU"), this deficiency poses a major obstacle to eliminating Roma segregation.

For many European countries, racial homogeneity has given way to a degree of heterogeneity with the arrival of immigrants from Asia, the Middle East and Africa. In an effort to eschew a milieu of discrimination, European discourse has revolved around indirect discussions of race, focusing instead on 'ethnicity' and 'national minorities,' and on 'prejudice' or 'xenophobia' rather than 'racism'-even where race is clearly at issue. As previously discussed, modern Europe's unwillingness to address racism directly is a legacy of atrocities committed during the Second World War. The unwillingness stems from a fear that using the rhetoric of racial differences could lead down a slippery slope to racial and ethnic profiling. In avoiding the term 'race' in favor of terms such as 'ethnic minority,' however, Europe is making it easier for those who deny universal equality on the basis of skin color to brush racial differences under vague, blanket terms that apply equally to German-speaking white minorities in Hungary as they do to Bangladeshi immigrants in the UK and to Roma in Slovakia. For instance, if a white, German-speaking Hungarian individual is an ethnic minority in the same manner as a Roma individual, discrimination against the Roma individual will likely be subsumed into a general discussion of ethnicity that fails to identify the vastly different circumstances surrounding each individual. The challenges facing white ethnic minorities will inevitably be different than those facing non-white minorities, whether immigrants or historical minorities.

This section examines some of the key legal instruments and decisions in the European Union relating to anti-discrimination through the lens of critical race theory; particularly the Race Equality Directive, and the jurisprudence and roles of the CJEU and the ECtHR. This analysis illustrates 
that weaknesses in European anti-discrimination law alone are insufficient to explain the continued educational segregation of Roma children. Instead, I argue that continued failure to desegregate schools is a result of racism and systemic discrimination against the Roma that is so profound as to make effective legal action nearly impossible; especially given that legislative measures are ineffective without proper enforcement. Within these instruments, however, lie the seeds of justice, waiting to be sown.

\section{A. The Race Equality Directive}

The 2000 Race Equality Directive was a key development in European anti-discrimination law, particularly given the broader context of EU antidiscrimination law and jurisprudence. As an economic union comprised of independent nations, the European Union focused historically on facilitating market access among its Member States rather than on furthering individual rights. In this sense, anti-discrimination law in the European Union differs from national anti-discrimination laws derived from constitutional principles or from international human rights laws in that it focuses primarily on marketplace activities. ${ }^{111}$

The original treaty establishing the European Economic Community ("EEC"), the predecessor to the European Union, included a provision requiring equal pay between genders. ${ }^{112}$ The motivations underlying the provision were economic and unrelated to gender equality, however. France - having already implemented similar equal pay provisions — was concerned about unfair economic competition given that female labor could be obtained at lower cost elsewhere in the EEC. ${ }^{113}$ In 1976, the CJEU, in the seminal case Defrenne II, ruled that Article 119 on equal pay had a social as well as an economic aim and opened the door to the European Union's involvement with fundamental human rights. ${ }^{114} \mathrm{~A}$ series of cases concerning gender-based discrimination followed. ${ }^{115}$ However, it was not until the Treaty of Amsterdam in 1997 that the European Union gained the power to legislate against discrimination with Article 19 of the Treaty on the

111. See Dagmar Schiek, Organizing EU Equality Law Around the Nodes of 'Race', Gender and Disability, in EUROPEAN UNION NON-DISCRIMINATION LAW AND INTERSECTIONALITY: INVESTIGATING THE TRIANGLE OF RACIAL, GENDER AND DisABILITY DisCRIMINATION, supra note 32, at 11, 20.

112. Treaty Establishing the European Economic Community, art. 119, Mar. 25, 1957, 298 U.N.T.S. 11.

113. Susanne Burri \& Sacha Prechal, European Commission, EU Gender Equality Law: UPDATE 2013, 2 (2014).

114. Id. at 2 (citing Case 43/75, Gabrielle Defrenne v. Société anonyme belge de navigation aérienne Sabena, 1976 E.C.R. 455.

115. Id. at 21-24. 
Functioning of the European Union ("TFEU"). ${ }^{116}$ The Charter of Fundamental Rights of the European Union, which became legally binding in 2009 , took this a step further, formally enshrining both a prohibition of race-based discrimination ${ }^{117}$ and a right to education. ${ }^{118}$

Anti-discrimination law pertaining specifically to race is a relatively recent development within the European Union and its Member States. While most Western European countries had enacted provisions on constitutional equality and established general anti-discrimination laws by the early 1990s, only six countries had specific anti-racism legislation at that time. ${ }^{119}$ In 2000, the European Union passed Directive 2000/43 (the "Race Equality Directive"), which addresses race discrimination in a broad range of areas. ${ }^{120}$ The Directive's preamble explicitly states that an important goal is " $[\mathrm{t}$ ] e ensure the development of democratic and tolerant societies which allow the participation of all persons irrespective of racial or ethnic origin." 121 To achieve this goal, "specific action in the field of discrimination based on racial or ethnic origin should go beyond access to employed and self-employed activities and cover areas such as education, social protection including social security and health-care, social advantages and access to and supply of goods and services." 122 The goal above is reiterated in greater detail in Article 3 of the Directive, which defines the Directive's scope and specifies that its non-discrimination requirements apply to "all persons, as regards both the public and private sectors, including public bodies." 123 Under this broad mandate, the Race Equality Directive covers more than equivalent EU legislation countering discrimination based on gender, sexual orientation, religion and belief, disability, or age. ${ }^{124}$

The Race Equality Directive explicitly embraces the European Union's role as an upholder of fundamental rights and recognizes that the European

116. See Schiek, supra note 111, at 12 .

117. Charter of Fundamental Rights of the European Union, 2010 O.J. (C 83) 389, Art. 21(1). The Charter prohibits discrimination on any grounds including "sex, race, colour, ethnic or social origin, genetic features, language, religion or belief, political or any other opinion, membership of a national minority, property, birth, disability, age or sexual orientation."

118. Id. at art. 14 .

119. Jan Niessen \& Isabelle Chopin, The Starting Line and the Racial Equality Directive, in THE DEVELOPMENT OF LEGAL INSTRUMENTS TO COMBAT RACISM IN A DIVERSE EUROPE 95, 98 (Jan Niessen \& Isabelle Chopin eds., 2004).

120. Council Directive 2000/43, pmbl. para. 12, 2000 O.J. (L 180) 43, 22 (EC) [hereinafter Race Equality Directive].

121. Id.

122. Id.

123. Id. at art. 3 .

124. Schiek, supra note 111 , at 15 . 
Union must go beyond its traditional economic mandate. Nevertheless, the Race Equality Directive, like all other EU directives, does not have horizontal direct effect-individuals cannot bring claims against other individuals on the basis of the Directive alone. Instead, the Directive requires Member States to implement its provisions within their national laws. This arguably dilutes the Directive's effectiveness. Within the European Union, only two non-discrimination rights are directly effective-gender and nationality of a Member State. All other non-discrimination rights must first be transposed into national law to be effective. ${ }^{125}$

Given European discomfort with the use of terminology relating to race, the Race Equality Directive was carefully worded to avoid the possibility of misconstruction. The Directive's preamble expressly disclaims any adherence to theories of racial difference, stating that " $\mathrm{t}]$ he European Union rejects theories which attempt to determine the existence of separate human races. The use of the term 'racial origin' in this Directive does not imply an acceptance of such theories." 126

The Directive represents a shift in the European conceptualization of racial discrimination in two ways. First, it accepts, albeit reluctantly, the premise that racism exists in Europe, a necessary step in addressing racial discrimination in a legal setting, for without acknowledgment of the problem, no lasting solution can be found. ${ }^{127}$ Second, prior to the enactment of the Race Equality Directive, most efforts to address racial discrimination were channeled through criminal law. ${ }^{128}$ In this latter respect, the Race Equality Directive represents a crucial mechanism for addressing indirect discrimination - the most challenging form of discrimination to prove and the variety most frequently exhibited in cases of school segregation. Article 2(2)(b) of the Race Equality Directive defines indirect discrimination as situations "where an apparently neutral provision, criterion or practice would put persons of a racial or ethnic origin at a particular disadvantage compared with other persons." 129 This definition suggests that a finding of indirect discrimination may be made even in the absence of thorough statistical data, indicating a divergence from earlier jurisprudence relating to gender-based discrimination where statistical evidence was required for findings of

125. Id.

126. Race Equality Directive, supra note 120, at pmbl. para. 6 .

127. See, e.g., MöSCHEL, supra note 49, at 128. As Möschel notes, "[t]he reluctance to frame objects or situations in terms of race also extends to a reluctance to frame persons as racists or their behaviour in terms of racism. Consequently, a narrow legal definition of racism and a racist under law emerges. In fact, not talking about race has all but eliminated racism in the legal realm."

128. Id. at 138 .

129. Race Equality Directive, supra note 120, at art. 2(2)(b). 
indirect discrimination. ${ }^{130}$ The Directive's shift is also illustrated in its provisions relating to the burden of proof in discrimination claims. Article 8 shifts the burden of proof and requires respondents to prove there has been no breach of the principle of equal treatment. ${ }^{131}$ The plaintiff's responsibility is to "establish, before a court or other competent authority, facts from which it may be presumed that there has been direct or indirect discrimination." 132 This burden is arguably less onerous than proving the existence of discrimination. This shift in the burden of proof places victims in a much stronger procedural position. ${ }^{133}$

Affirmative action - or positive action, as known in the European Union - is explicitly permitted but not required under Article 5 of the Race Equality Directive. Article 5 provides that "the principle of equal treatment shall not prevent any Member States from maintaining or adopting specific measures to prevent or compensate for disadvantages linked to racial or ethnic origin." 134 Positive action is grounded in the principle of substantive equality, as it allows for unequal treatment to rectify disadvantages created by the underlying discrimination in order to achieve equality in fact. ${ }^{135}$ As such, positive action emphasizes the victim's perspective rather than the perpetrator's perspective.

Positive action has been widely recognized as a prerequisite for achieving equality. In 2000, the Council of Europe-a broader European institution of which the European Court of Human Rights is a part-issued a recommendation for furthering Roma education that suggested establishing support structures to help Roma children succeed in schools, particularly through positive action. ${ }^{136}$ In the European Union, the CJEU has been relatively restrictive in its interpretation of positive action with regards to gender discrimination, often favoring procedural over substantive

130. Sejal Parmar, The European Court of Justice and Anti-Discrimination Law: Some Reflections on the Experience of Gender Equality Jurisprudence for the Future Interpretation of the Racial Equality Directive, in THE DEVElopment of LEGAL InSTRUMENTS TO COMBAT RACISM IN A DiverSE EUROPE 131, 145 (Jan Niessen \& Isabelle Chopin eds., 2004); see also HowARD, supra note 61, at 144.

131. Race Equality Directive, supra note 120, at art. 8(1).

132. Id.

133. Case C-394/11,Valeri Hariev Belov v. CHEZ Elektro Balgaria AD and Others, Opinion of Advocate General Kokott, ECLI:EU:C:2012:585, at para. 91 (Belg.) [hereinafter Belov, AG Opinion].

134. Race Equality Directive, supra note 120, at art. 5; see also Belov, AG Opinion, supra note 133 at pmbl. para. 17.

135. HOWARD, supra note 61 , at 115 .

136. Council of Europe: Committee of Ministers, Recommendation No. R(2000)4 of the Committee of Ministers to Member States on the Education of Roma/Gypsy Children in Europe, 3 Feb. 2000, at App. I(6). 
equality. ${ }^{137}$ Although the CJEU has yet to deal with cases of positive action involving race discrimination, it will likely follow a jurisprudential path similar to that established in relation to gender discrimination; particularly since the wording of the positive action provision in the Race Equality Directive is identical to the positive action provision in the Gender Equality Directive. ${ }^{138}$ While a number of EU Member States have expressed their commitment to positive action in relation to the Roma-including as part of the Decade of Roma Inclusion - these commitments have rarely resulted in substantive change. ${ }^{139}$

Thus far, the Race Equality Directive has failed to meet expectations. Since its enactment in 2000, only three cases before the CJEU have concerned the interpretation of substantive provisions of the Race Equality Directive. One of these cases involved a Belgian company that openly refused to hire immigrant employees. ${ }^{140}$ The other two cases involved Roma. ${ }^{141}$ The first case, Belov, was dismissed because the referring national body was not considered a court and thus lacked the authority to refer the dispute to the CJEU. ${ }^{142}$ The second case, CHEZ RB, provided meaningful clarification of the Directive. These cases are discussed in greater detail below.

The drafting of the Race Equality Directive also raises some concerns. In particular, the Directive's failure to define "racial segregation" creates difficulties when addressing cases of educational segregation. ${ }^{143}$ The Directive also somewhat problematically allows for the justification of indirect discrimination where there is a legitimate aim and the means of achieving that aim are appropriate and necessary. In contrast, direct discrimination cannot be justified unless it results from a "genuine and

137. For commentary on the interpretation of "positive action" by the CJEU in cases of gender discrimination, see O'NIONS, supra note 6, at 90; see also HowARD, supra note 61, at 152.

138. See Council Directive 2004/113, art. 6, 2004 O.J. (L 373) 37 (EC) [hereinafter Gender Equality Directive] (implementing the principle of equal treatment between men and women in the access to and supply of goods and services); Race Equality Directive, supra note 120, at art. 5.

139. Taba \& Ryder, supra note 38 , at 23.

140. Case C 54/07, Centrum voor gelijkheid van kansen en voor racismebestrijding v Firma Feryn NV 2008 E.C.R. I-05187 (Belg.) [hereinafter Feryn, Judgment].

141. Case C-394/11, Valeri Hariev Belov v. CHEZ Elektro Balgaria AD and Others, 2013 ECLI:EU:C:2013:48 [hereinafter Belov Judgment]; Case C-83/14, CHEZ Razpredelenie Bulgaria AD v. Komisia za zashtita ot diskriminatsia, 2015 ECLI:EU:C:2015:480 [hereinafter CHEZ RB, Judgment].

142. Belov Judgment, III 54-55.

143. See Iulius Rostas, Judicial Policy Making: The Role of the Courts in Promoting School Desegregation, in TEN YEARS AFTER: A History OF ROMA SCHOOL DESEGREGATION IN CENTRAL AND EASTERN EUROPE 91, 97 (Iulius Rostas ed. 2012). Rostas notes that there is no proper definition of racial segregation in the European Convention on Human Rights, nor is there a proper definition provided by international organizations. 
determining" occupational requirement, or is the result of positive action. ${ }^{144}$ This controversial allowance permits national courts to accept improper justifications for indirect discrimination in such a manner that undermines the effectiveness of the Directive's provision on indirect discrimination.

\section{B. Data Privacy}

Data collection and privacy are closely related to the Race Equality Directive and to questions surrounding its effectiveness. Because of historical concerns regarding racial and ethnic profiling, European privacy law limits the collection of data on racial and ethnic minorities. Even the idea of data collection frightens many Europeans. ${ }^{145}$ Consequently, one of the biggest challenges facing advocates for Roma equality is the accessibility of adequate statistical proof of direct or indirect discrimination. ${ }^{146}$ Data collection is crucial in uncovering evidence of indirect discrimination; data is critical in demonstrating the discriminatory effects of facially neutral policies. Even the population size of the Roma in Europe varies wildly between official and unofficial estimates as a result of data collection issues. As Lilla Farkas states in her report on the educational segregation of Roma children, "[1]ack of data does not only seriously hinder the creation of policies or positive action measures, but may pose serious challenges to effective judicial protection from structural discrimination in education." ${ }^{147}$ Furthermore, although most EU Member States have enacted positive action policies to aid Roma communities, the lack of accurate data means that the impact of these policies is often unknown. ${ }^{148}$ EU Member States have also cited the lack of accurate data in response to claims of discrimination and segregation against the Roma. ${ }^{149}$ On the flipside, years of persecution by majority populations have made the Roma, like members of other persecuted ethnic and racial minority groups, wary of what governments may do with

144. Race Equality Directive, supra note 120, at arts. 2, 4, 5; see also HowARD, supra note 61, at 146. Howard posits that perhaps the justification of indirect discrimination is because the EU legislators viewed direct discrimination as more offensive and repugnant.

145. Timo MaKkonen, European COMmission, MEASuring Discrimination: Data COLLECTION AND EU EQUALITY LAW 13 (2006), http://ec.europa.eu/social/BlobServlet?docId=1687\&la ngId=en [https://perma.cc/FCF3-ZGYC].

146. See MAKKONEN, supra note 145, at 40 (discussing the usefulness of statistical data in the context of legal proceedings on discrimination).

147. FARKAS, supra note 19, at 5 .

148. Id.; see also Greenberg, supra note 37, at 927 (noting that "[t]he lack of demographic information often prevents targeted efforts to meet the needs of distinct populations. It is nearly impossible to assess whether or not programs designed to aid Roma citizens are actually working").

149. See FARKAS, supra note 19, at 37-38. 
data on their Roma identity. ${ }^{150}$ As a result of the Roma's unwillingness to provide personal data, even when governments are willing and able to collect aggregate data about the Roma, the information they collect is often inaccurate.

The 1995 Data Privacy Directive provides the basis for the European Union's data collection policies. The Directive aims to protect individuals with regards to the processing of their personal data and with respect to where the data is sent outside of the European Union. ${ }^{151}$ Contrary to common belief, this does not forbid all data processing. Data processing is permitted so long as the subject of the data provides their consent, or, absent consent, if data processing is a necessary component of legal proceedings, or as part of activities by public authorities to ensure equal treatment. ${ }^{152}$ Most significantly, EU data privacy regulations do not apply to the aggregate collection of data relating to societal or cultural groups, or to the categorization of data by ethnicity. ${ }^{153}$ The Data Privacy Directive is focused on protecting individuals' personal data rather than the protection of group data. ${ }^{154}$ Nevertheless, the supposed restrictions on data processing have been used by governments as an excuse to justify their inability or unwillingness to furnish data on school demographics. ${ }^{155}$ At the same time, these governments have willingly provided data concerning demographics in relation to crime. Such governmental behavior suggests that data processing has become a selective exercise, and that the Data Privacy Directive is often wielded as a shield against providing data that would support the existence of widespread school segregation.

The importance of accurate statistical data in segregation cases cannot be overstated. While the Race Equality Directive appears to have moved away from the stringent statistical evidentiary requirements in gender discrimination cases, statistics remain crucial in establishing structural discrimination in education. ${ }^{156}$ In this sense, the relevance of statistics goes beyond proving disparate impact in cases of indirect discrimination; indeed, data demonstrating ethnic or racial disproportionality between schools or

150. UNICEF, supra note 4 , at 39 .

151. Council Directive 95/46, 1995 O.J. (L 281) 31, 31 (EC).

152. FARKAS, supra note 19, at 36 (citing MAKKONEN, supra note 145, at 85).

153. UNICEF, supra note 4 , at 39.

154. See MAKKONEN, supra note 145, at 72.

155. Lilla Farkas has noted that "[1]itigation experience in Hungary shows that respondents merrily invoke data protection provisions in an attempt to defend their refusal to furnish even school or grade level aggregate data on Roma." FARKAS, supra note 19, at 37.

156. See id. at 41 ; see also MAKKONEN, supra note 145 , at 15 (noting that data collection is particularly relevant to findings of indirect discrimination). 
classrooms is required to establish a prima facie case of segregation. ${ }^{157}$ Adding to the difficulty for potential plaintiffs in indirect discrimination cases is that in order to determine if there is a prima facie case of discrimination, they would realistically need access to the data before bringing the claim. ${ }^{158}$

The challenges with data collection and data privacy in relation to the segregation of Roma children are twofold. So long as governments may selectively choose which data to provide while hiding behind inaccurate interpretations of the Data Privacy Directive, situations of indirect discrimination will remain difficult to prove. Additionally, as long as the Roma are wary of government and unwilling to provide accurate data in censuses and elsewhere, the data available will remain an inadequate reflection of discrimination. Addressing these challenges requires transparent policies governing data collection, greater institutional capacity with regards to data collection, and active engagement with Roma communities to alleviate their privacy concerns. ${ }^{159}$

C. The European Court of Justice and the Race Equality Directive

As previously mentioned, there are currently only three judgments of the CJEU on the Race Equality Directive-Feryn, Belov and CHEZ RB. Belov and CHEZ RB addressed situations involving discrimination against the Roma. Feryn, the first CJEU case to interpret the Race Equality Directive, involved a Belgian company whose director issued public statements refusing to hire Moroccans after posting a job vacancy notice. ${ }^{160}$ The Feryn Court held that public statements by an employer refusing to hire employees of a certain ethnic or racial background does constitute direct discrimination, since such statements are likely to dissuade certain candidates from applying for the job. ${ }^{161}$ This was a fairly straightforward case and did not require the Court to provide nuanced interpretations of the Directive.

157. FARKAS, supra note 19 , at 38.

158. MAKKONEN, supra note 145, at 29; see also EUROPEAN UNION AGENCY FOR FUNDAMENTAL RightS AND COUNCIL OF EUROPE, HANDBOOK ON EUROPEAN NON-DISCRIMINATION LAW 124 (2010), http://www.echr.coe.int/Documents/Handbook_non_discri_law_ENG_01.pdf [https://perma.cc/ELR4YXK5] ("In order to raise a presumption of indirect discrimination, a claimant may need to rely on statistical data that proves general patterns of differential treatment.")

159. See UNICEF, supra note 4, at 39.

160. Feryn, Judgment, supra note 140, III 2-3.

161. Id. $\llbracket 30$. 
The Belov case arose on a request by a Bulgarian body for a preliminary ruling clarifying several of the Directive's provisions. ${ }^{162}$ The situation that prompted the request involved the placement of electricity meters at 7 meters in height (23 feet) in two majority Roma districts in the Bulgarian city of Montana in response to concerns regarding fraud and abuse of the electricity supply. The customary height for electricity meters elsewhere was 1.7 meters (5.5 feet), allowing customers to check their electricity usage. ${ }^{163}$ The question facing the Court was whether the abnormal placement of the meters constituted discrimination based on ethnic origin. Mr. Belov, a Roma resident in one of the two districts, brought the complaint before the Commission for Protection against Discrimination ("KZD"), a body established as part of Bulgaria's transposition of the Race Equality Directive into its national law. ${ }^{164}$

The CJEU has interpretive jurisdiction to answer questions on the application of EU law when posed by national courts or tribunals. The questions submitted by the KZD in Belov were insightful and responses by the CJEU would have clarified numerous points concerning the interpretation of the Race Equality Directive; particularly regarding the interpretation of "less favorable treatment" in relation to direct discrimination under Article 2(2)(a) and the meaning of "indirect discrimination" as defined in Article 2(2)(b) of the Directive. ${ }^{165}$ As is typical in cases of first impression, the Court decided an opinion from the Advocate General was needed. Advocate General Juliane Kokott, provided a wellreasoned opinion in September 2012. The Bulgarian referring body, KZD, took its mandate from the European Union under Article 13 of the Race Equality Directive and was tasked with defending the rights of those facing discrimination. In her opinion, as a threshold matter before addressing several legal questions, Kokott determined that the body was in fact a court or tribunal with authority to refer questions for a preliminary ruling. ${ }^{166}$

Among AG Kokott's findings, she recognized that contrary to how the Directive had been transposed into Bulgarian law, less favorable treatment did not exist only where rights or interests defined in law were infringed

162. Belov, AG Opinion, supra note 133, I[ 1; Belov, Judgment, supra note 141, I[ 1.

163. Belov, AG Opinion, supra note 133, II 2.

164. Id. IIII $14,19$.

165. Id. $\llbracket 21$.

166. These include "whether the body is established by law, whether it is permanent, whether its jurisdiction is compulsory, whether its procedure is inter partes, whether it applies rules of law and whether it is independent. Furthermore, national bodies may refer a question to the Court only if there is a case pending before them and if they are called upon to give judgment in proceedings intended to lead to a decision of a judicial nature." Id. \I 26. 
directly or indirectly. ${ }^{167}$ Neither direct nor indirect discrimination under the Race Equality Directive requires an infringement of rights or interests defined in law. The only requirement for the existence of direct or indirect discrimination is that there be less favorable treatment or a disadvantage. ${ }^{168}$ If national laws are contrary to the prohibition of discrimination as established at the EU level, national courts are obliged not to apply such laws. ${ }^{169}$

Specifically in relation to the facts in Belov, AG Kokott found no direct discrimination since the installment of the electricity meters affected consumers primarily by way of their residential location rather than their ethnicity. ${ }^{170}$ However, since the affected districts were inhabited primarily by Roma, the installation of the electricity meters disproportionately affected the Roma, resulting in a prima facie case of indirect discrimination based on ethnic origin. ${ }^{171}$ Under Article 2(2)(b) of the Race Equality Directive, Advocate General Kokott clarified that indirect discrimination can be legal "if it is objectively justified by a legitimate aim and the means of achieving that aim are appropriate and necessary," or "proportionate." ${ }^{172}$ However, even if the measures are justified by a legitimate aim and the means are appropriate and necessary, the principle of proportionality is violated if they have undue adverse effects on the residents of the districts. ${ }^{173}$ Kokott concluded that measures like the meter installations at issue could be justified only if they prevented fraud and abuse, provided that there were "no other, equally suitable measures" that could be taken "to achieve those aims at a financially reasonable cost, which would have less detrimental effects" on the local population. ${ }^{174}$ Additionally, the measure must not result in undue adverse effects on the residents of the districts in question. ${ }^{175}$

In January 2013, the CJEU issued its judgment in Belov, ignoring the Advocate General's opinion and finding that the body that referred the question to the Court was not sufficiently of a judicial nature to qualify as a national court. ${ }^{176}$ As such, the CJEU dismissed the case for lack of jurisdiction. This result was considered disappointing, since the CJEU side-

\author{
167. Id. IIII 69-73. \\ 168. Id. III 71,83 . \\ 169. Id. II 83. \\ 170. Id. II 97. \\ 171. Id. II 99 . \\ 172. Id. If 100 . \\ 173. Id. II 117 . \\ 174. Id. II 124. \\ 175. Id. \\ 176. Belov, Judgment, supra note 141, If 54.
}


stepped an opportunity to clarify important points regarding interpretation of the Race Equality Directive. By dismissing the case on technical grounds, the Court avoided ruling on key issues of racial discrimination under the Race Equality Directive.

The most recent CJEU case to address the Race Equality Directive was CHEZ $R B .{ }^{177}$ CHEZ RB involved another request for a preliminary ruling concerning a very similar factual scenario to Belov; the installation of electricity meters at inaccessible heights in a primarily Roma district in the Bulgarian town of Dupnitsa. ${ }^{178}$ The plaintiff in the case, Anelia Georgieva Nikolova, was a non-Roma owner of a small shop in the Roma district of Dupnitsa. ${ }^{179}$ One question raised by the case, therefore, was whether it was possible for non-members of a particular ethnic group to suffer discrimination by association. ${ }^{180}$ In her March 2015 opinion, Advocate General Kokott referenced her opinion in Belov, noting that CHEZ RB allowed her an opportunity to delineate more clearly the difference between direct and indirect discrimination based on ethnic origin. ${ }^{181}$ In her written opinion, Kokott drew an analogy between the plaintiff and a group of individuals who are denied a lunch table because of one group member's race. ${ }^{182}$ According to Kokott, this situation would qualify not only as discrimination against the individual member, but also against the other group members who suffer discrimination by association, since none of the group end up being served. ${ }^{183}$

Without a preliminary issue allowing for dismissal on technical grounds - as in Belov - the Court in CHEZ RB openly addressed the question of discrimination under the Race Equality Directive. The Court referred to ECtHR jurisprudence in discussing the European conception of ethnicity and found that Roma origin qualified as an established ethnicity. ${ }^{184}$ In relation to Ms. Nikolova's position, the Court agreed with Advocate General Kokott's opinion and held that discrimination under the Race Equality Directive can extend to individuals who, "although not themselves a member of the race or ethnic group concerned, nevertheless suffer less favourable treatment or a

177. CHEZ RB, Judgment, supra note 141; Case C-83/14, CHEZ Razpredelenie Bulgaria AD v. Komisia za zashtita ot diskriminatsia, Opinion of Advocate General Kokott, ECLI:EU:C:2015:170 (2015), II 2 [hereinafter CHEZ RB, AG Opinion].

178. CHEZ RB, Judgment, supra note 141, IIII 19-22.

179. Id. IIII 21-22.

180. See CHEZ RB, AG Opinion, supra note 177, II 4.

181. Id.

182. Id. II 59.

183. Id.

184. CHEZ RB, Judgment, supra note 141, II 46. 
particular disadvantage on one of [the grounds enumerated in Article 1]." 185 In other words, although Ms. Nikolova was not Roma, she was affected by the placement of the electricity meters in a primarily Roma district, such that she also suffered from less favorable treatment.

Building on Kokott's opinion, the CJEU also held that national provisions which limit the scope of "less favorable treatment" or a "particular disadvantage," as referred to in Articles 2(2)(a) and 2(2)(b), to only those acts that prejudice a "right" or a "legitimate interest" of a person, ultimately restrict the scope of the protections the Directive is meant to guarantee. ${ }^{186}$

In addressing requests for preliminary rulings, the CJEU is limited to interpreting EU Treaties and EU law. While it can interpret EU law for the benefit of national courts, it cannot issue a definitive ruling on whether particular actions violate EU law. ${ }^{187}$ The CJEU issued a judgment in July 2015 recognizing the possibility of a finding of direct discrimination, but it ultimately left a final determination up to the Bulgarian court. CHEZ RB clarified the scope of the Race Equality Directive and was the first ruling under the Directive to address Roma discrimination. By holding that the Directive applied to discrimination by association, the CJEU adopted an inclusive interpretation of discrimination, and paved the way for future challenges to anti-Roma discrimination. The limitations of the CJEU's rulings, however, rest with the Court's limited to effect change unless infringement proceedings are brought before it under Articles 258 and 259 of the TFEU, as discussed below. National courts, who make requests for preliminary rulings, have ultimate authority to determine if discrimination exists, in fact. With regards to school segregation, the finding by the CJEU that discrimination by association is subject to redress under the Race Equality Directive as a violation of a fundamental right does not provide meaningful protection for Roma children, since their segregation results in situations where it is precisely that association that they lack. In that respect, cases of segregation are more straightforward findings of discrimination. The precedent set by the CJEU in CHEZ RB illustrates that if discrimination can be found in a more attenuated situation, then school segregation may also qualify as discrimination.

$C H E Z R B$ represents a milestone in CJEU jurisprudence relating to the Race Equality Directive. After Belov's emphasis on procedural issue, $C H E Z$ $R B$ offered the CJEU an opportunity to interpret the Race Equality Directive

185. Id. II 56

186. Id. গIII 68-69.

187. Id. II 71 . 
and address difficult questions relating to direct and indirect discrimination. CHEZ RB could open the door for more cases involving discrimination against the Roma, but either national courts must be willing to refer such questions, and the European Commission or another EU Member State must be willing to initiate infringement proceedings against countries discriminating against the Roma.

Infringement proceedings allow the European Union to take action against Member States that violate EU law. As previously mentioned, Article 258 of the TFEU addresses infringement procedures. The Article allows the European Commission to issue an opinion on a Member State's failure to fulfill obligations under the EU treaties before bringing the matter before the CJEU, should the Member State not comply with the opinion. ${ }^{188}$ Article 259 allows Member States to bring matters regarding other Member States' infringement of treaty obligations before the Commission, with the possibility of later bringing such matters before the CJEU. ${ }^{189}$ Articles 258 and 259 may arguably be the most effective supranational tools available to combat segregation at the national level.

In September 2014, the European Commission initiated infringement proceedings under Article 258 of the TFEU against the Czech Republic for violating EU anti-discrimination law by segregating Roma children into special education schools. ${ }^{190}$ The Commission took similar action against Slovakia in April 2015. ${ }^{191}$ The European Commission initiated infringement proceedings against Hungary in May 2016 to address the continued segregation of Roma children in Hungarian schools. ${ }^{192}$ These represent the first cases in which the European Commission has taken EU Member States to task for failing to meet their obligations under EU anti-discrimination law.

In response to these proceedings, both the Czech Republic and Slovakia proposed measures to address the discrimination of Roma students; primarily as a means of forestalling further action by the European Commission. The Czech Republic adopted several amendments to their education law, including an amendment introducing one year of compulsory pre-school

188. Consolidated Version of the Treaty on the Functioning of the European Union, art. 258, 2008 O.J. (C 115) 47 [hereinafter TFEU].

189. TFEU, art. 259.

190. Press Release, European Roma Rights Centre, Commission Takes Tougher Stance on Member States Discriminating Roma (Apr. 29, 2015), http://www.errc.org/article/commission-takes-tougherstance-on-member-states-discriminating-roma/4359 [https://perma.cc/5JNB-FC7G].

191. Id.

192. Press Release, Amnesty International, EU Commission Probe Must Spell the End of Romani Segregation in Hungarian Schools (May 26, 2016), http://www.amnestyusa.org/news/press-releases/eucommission-probe-must-spell-the-end-of-romani-segregation-in-hungarian-schools [https://perma.cc/C2 4Z-G28R]. 
education. ${ }^{193}$ The country is also considering eliminating educational programs for students with mild learning disabilities. ${ }^{194}$ These measures suggest that the Czech Republic may finally be taking the educational segregation of Roma children seriously and adopting substantive measures to combat it. The Slovak Parliament passed an amendment to their education law in June 2015 which purports to promote integration and provides financial incentives to schools educating students from disadvantaged backgrounds. However, the amendment fails to eliminate ethnic discrimination against the Roma. ${ }^{195}$ In contrast to the Czech measures, the Slovak measures arguably do little more than pay lip service to the requirements of EU anti-discrimination law. To date, the European Commission has taken no further action regarding either Slovakia or the Czech Republic.

The steps taken by the Czech Republic and Slovakia to amend their laws do not necessarily guarantee the countries' compliance with EU antidiscrimination law. The European Commission has discretion to continue its proceedings and engage in further fact finding if it determines measures implemented by EU Member States are inadequate. In Article 258 proceedings, if the Commission uncovers an infringement it may then bring the case before the CJEU. The CJEU cannot itself initiate proceedings, and it is up to the European Commission to work with the CJEU to make sure violations of the Directive by EU Member States are properly dealt with.

These proceedings suggest that the European Union is taking a more proactive role in condemning Roma discrimination. However, the European Commission's newfound willingness to initiate infringement proceedings against Member States may be more a product of interest convergence than of a genuine belief in the necessity of eliminating discrimination against the Roma. The European Commission's reaction to Slovakia's new law, referenced above, will be instructive in this regard.

Despite its jurisprudential influence, the CJEU, while best situated to provide judicial opinions on the implementation of anti-discrimination provisions under the Race Equality Directive, is ill-equipped to adjudicate human rights cases. As Gráinne de Búrca argues, with the increase in rightsbased arguments before the CJEU, "[t]he self-referential, formulaic and often minimal style of the single collegiate judgment seems increasingly ill-

193. AmNesty InTERNATIONAL, ANNUAL Report: CZECH RePUblic 2015/2016 135 (Mar. 2016), https://www.amnesty.org/en/countries/europe-and-central-asia/czech-republic/report-czech-republic/ [https://perma.cc/CK53-SEWX].

194. Id.

195. Id. at 322 . 
suited to the changing circumstances and docket of the Court." ${ }^{196}$ Combined with the limited avenues by which cases may reach the CJEU, this means that even if motivated by a desire to change the face of discrimination against the Roma throughout Europe, CJEU judges are limited by the level of activism of the European Commission and the willingness of national courts to place themselves before the CJEU. Despite these limitations, the CJEU's judgment in CHEZ RB offers hope for future cases involving Roma that reach the Court, since the Court appears willing to interpret discrimination in a manner that offers victims meaningful protection.

D. The Jurisprudence of the European Court of Human Rights on the Segregation of Roma Children

While the CJEU has limited jurisprudence addressing issues of racial discrimination, the European Court of Human Rights has heard numerous cases involving discrimination against the Roma, both in education and in other areas such as police brutality. The ECtHR is an international court established by the Council of Europe under the auspices of the European Convention on Human Rights that deals specifically with human rights violations. ${ }^{197}$ The jurisprudence of the ECtHR has interpreted direct and indirect discrimination in a similar fashion to the jurisprudence of the CJEU, although the European Convention on Human Rights does not explicitly address the difference between direct and indirect discrimination, unlike the Gender Equality and Race Equality Directives. Article 14 of the European Convention on Human Rights prohibits discrimination on any ground, including "sex, race, color, language, religion, political or other opinion, national or social origin, association with a national minority, property, birth or other status." ${ }^{198}$ Article 2 of Protocol No. 1 of the European Convention on Human Rights recognizes education as a fundamental right, stating that "[n]o person shall be denied the right to education. ${ }^{199}$ Segregation cases have been brought under Article 14 of the Convention read together with Article 2 of Protocol No. 1.

There have been six ECtHR judgments to date dealing with the segregation of Roma children: D.H. and Others v. the Czech Republic; Sampanis and Others v. Greece; Oršuš and Others v. Croatia; Sampani and Others v. Greece; Horváth and Kiss v. Hungary; and Lavida and Others v.

196. Gráinne de Búrca, After the EU Charter of Fundamental Rights: The Court of Justice as Human Rights Adjudicator?, 20 MAASTRICHT J. 168, 184 (2013).

197. The European Court of Human Rights has forty-seven member states.

198. Convention for the Protection of Human Rights and Fundamental Freedoms, Nov. 4, 1950, 213

U.N.T.S. 221, art. 14 [hereinafter European Convention on Human Rights].

199. European Convention on Human Rights, supra note 198, protocol 1, art. 2. 
Greece. With the exception of D.H. and Others and Oršuš and Others v. Croatia, which were ultimately decided by the Grand Chamber in its appellate capacity, each of the decisions above were decided unanimously in favor of the Roma students; each time without a subsequent appeal. ${ }^{200}$ In D.H. and Others and Oršuš and Others v. Croatia, the ECtHR found in favor of the Roma students on appeal. However, in each case the ECtHR ultimately failed to order substantive relief. The seminal Roma school segregation ECtHR case, D.H. and Others, ${ }^{201}$ has been compared to Brown v. Board of Education by scholars and activists alike. While Brown had nationwide impact, the judgment in D.H. and Others dealt exclusively with segregation in the Czech Republic, limiting the wider impact of the ECtHR's judgment.

In D.H. and Others, the plaintiffs were eighteen Roma school children who had been placed in special needs schools in the Czech Republic. In the region where the plaintiffs lived, only $1.8 \%$ of non-Roma students had been placed in special schools, compared to $50.3 \%$ of Roma students. ${ }^{202}$ After their placement in the schools, the majority of the plaintiffs requested that the administrative placement decisions be reviewed, on the basis that their intellectual capabilities had been improperly tested and they had been unaware of the consequences of consenting to placement in the special needs schools. ${ }^{203}$ Twelve of the plaintiffs lodged constitutional appeals before the highest Czech court, the Constitutional Court, and argued that the placement of Roma children in special needs schools amounted to de facto racial segregation since two separate educational systems existed-normal schools for the white majority and special schools for the Roma. ${ }^{204}$

Unlike in Brown, where the constitutional permissibility of segregation was challenged, in D.H. and Others the question was not whether segregation was permissible (it clearly was not), but whether segregation was present given that Roma students were being placed in special schools at much higher rates than their non-Roma peers. ${ }^{205}$ However, in other respects, Brown and D.H. and Others share many similarities. In both cases, the plaintiffs were representatives of their larger groups, since their experiences

200. Lilla FARKAS, EUROPEAN NETWORK OF LEGAL EXPERTS IN THE NON-DisCRiminAtion FIELD, REPORT ON DISCRIMINATION OF ROMA CHILDREN IN EDUCATION 27 (2014). D. H. and Others was decided in 2007; Sampanis and Others in 2008, Oršuš and Others in 2010, Sampani and Others in 2012 and Horváth and Kiss in 2013.

201. D.H. and Others v. the Czech Republic, App. No. 57325/00 Eur. Ct. H.R. (2007) [hereinafter D.H. and Others, Grand Chamber Judgment].

202. Id. II 18.

203. D.H. and Others v. the Czech Republic, App. No. 57325/00 Eur. Ct. H. R. (Feb. 7, 2006), II 13 [hereinafter D.H. and Others, Judgment].

204. Id. II 25.

205. Greenberg, supra note 37 , at 940-41. 
were collective, rather than individualized. In addressing the segregation of the Roma students, the Grand Chamber took an unusual approach and opted not to look at each student's case individually. Instead, the Grand Chamber found that the disproportionate placement of Roma students into special schools amounted to racial discrimination against the students collectively. ${ }^{206}$

As with Brown, D.H. and Others had little immediate impact and Roma students continue to be segregated despite legislative enactments by the Czech Republic aimed at abolishing special schools. ${ }^{207}$ Without a subsequent decision like Brown II in 1955 speaking directly to practical implementation, the ruling in D.H. and Others has largely been symbolic. Particularly troubling were the decision's timeframe and the damages awarded. D.H. and Others took seven and a half years to be decided and each victim was awarded a mere $€ 4,000$ (approximately $\$ 4,500) .{ }^{208}$ Since no desegregation order was issued as a result of the case-which would have arguably made the monetary award a symbolic token of a greater class-based award-the amount awarded seems pitifully small and insufficient to compensate for a lifetime of lost potential employment opportunities as a result of unjust placement into special education schools.

Derrick A. Bell's argument that Brown was not the product of a strong commitment to desegregation, but rather a result of interest convergence 209 applies equally to D.H. and Others. Subsequent ECtHR case law suggests a decline in the Court's support for findings of discrimination in cases involving educational segregation of the Roma. ${ }^{210}$ At the same time, the ECtHR has demonstrated marked unwillingness to find anti-Roma discrimination outside the context of educational segregation. ${ }^{211}$ The ECtHR has a reputation to uphold as a preeminent court of human rights, but also has to contend with member states with poor human rights records.

206. D.H. and Others, Grand Chamber Judgment, supra note 201, IIII 199-204.

207. Id. .ा 208.

208. Rostas, supra note 143 , at 106.

209. Bell, supra note 55, at 524 (arguing that the value of the Brown decision to whites wasn't just the value to those whites who were worried about the immorality of racial inequality, but the value to those in power who could see the economic and political advances that would occur as a result of desegregation).

210. See Mathias Möschel, Is the European Court of Human Rights' Case Law on Anti-Roma Violence 'Beyond Reasonable Doubt'?, 12 HuM. RTS. L. REV. 479, 496 (2012) (noting that the Grand Chamber majority on the finding that there was an Article 14 violation dwindled from 13-4 in D.H. and Others to 9-8 in Oršuš and Others).

211. Id. at 485 (Möschel notes that the ECtHR has been willing to find Article 2 and 3 violations, but rarely Article 14 discrimination violations, even when brought in conjunction with cases involving violence against Roma). 
Furthermore, European support for worldwide human rights initiatives stands in sharp contrast to its handling of discrimination within its own borders. With D.H. and Others, the ECtHR attracted substantial positive press coverage, and Roma activists hailed the decision as a significant step forward for Roma rights. The ECtHR lacks enforcement capabilities to lend real weight to its decisions, however, and the Roma students' "victory" in D.H. and Others was largely pyrrhic.

Sampanis and Others v. Greece was the second school segregation case involving Roma children decided by the ECtHR. In Sampanis, Roma students in Greece were repeatedly refused entry to a local primary school by non-Roma parents who physically blocked the Roma students. As a result, the Roma students were forced to study in a completely separate, prefabricated annex building created to prepare them for entry into normal primary school. ${ }^{212}$ The ECtHR's judgment built on its jurisprudence established in D.H. and Others and cemented the position taken by the Grand Chamber in D.H. and Others; namely, that where a prima facie case of discrimination is found, the burden of proof shifts from the complainant to the defendant. ${ }^{213}$ The Court in Sampanis failed, however, to clarify whether it viewed the segregation at issue as direct or indirect discrimination. ${ }^{214}$ Since the facts of the case suggested that explanations for the separate treatment of Roma students were post facto explanations on the part of the government to avoid a finding of segregation, Sampanis arguably provided a clear-cut case of direct discrimination - where Roma students are separated from nonRoma students purely based on race or ethnicity. However, the Court emphasized its reversal of the burden of proof, a principle which applies solely to indirect discrimination. ${ }^{215}$ Issuing a clear-cut finding of direct discrimination in would have strengthened the ECtHR's anti-discrimination jurisprudence, and would have helped clarify the scope of direct discrimination both for future ECtHR cases and for cases before the CJEU addressing discrimination under the Race Equality Directive.

Not long after the judgments in D.H. and Others and Sampanis and Others, the ECtHR issued a judgment in Oršuš and Others v. Croatia. Similar to the previous segregation cases, the applicants in Oršuš and Others

212. Affaire Sampanis et Autres c. Grèce (Sampanis and Others v. Greece), App. No. 32526/05 Eur. Ct. H.R. (June 5, 2008), IIII 18-23 [hereinafter Sampanis and Others, Judgment].

213. Sina van den Bogaert, Roma Segregation in Education: Direct or Indirect Discrimination?: An Analysis of the Parallels and Differences Between Council Directive 2000/43/EC and Recent ECtHR Case Law on Roma Educational Matters, 71 ZEITSCHRIFT FÜR AUSLÄNDISCHES ÖFFENTLICHES RECHT UND VÖLKERRECHT 721, 736 (2011).

214. Id. at 739 .

215. Sampanis and Others, Judgment, IIII 78-79. 
were primary school children who had been segregated into Roma-only classes, ostensibly to provide them with extra language instruction in Croatian. ${ }^{216}$ The Court found no discrimination and distinguished D.H. and Others on grounds that "placing a disproportionate percentage of children belonging to a specific ethnic minority in schools for the mentally retarded bears no comparison with placing Roma children in separate classes on the ground that they lack adequate knowledge of the Croatian language."217 Crucially, the Court determined unanimously that the segregation at issue was based not on ethnicity or race, but rather on adequacy of language skills. ${ }^{218}$ Despite the Court's unsatisfactory judgment, on appeal, a divided Grand Chamber ultimately found a violation of the prohibition of discrimination as read together with the right to education. Although the Roma students attended Roma-only classes on the same premises as other classes, and while it was not a general policy to automatically place Roma children into separate schools, the Grand Chamber found indirect discrimination because Roma children alone were affected by the policy, resulting in a difference of treatment. ${ }^{219}$

The most recent ECtHR decision addressing the segregation of Roma children was Horváth and Kiss. In Horváth and Kiss, two Roma children were classified as mentally disabled under criteria established by Hungarian legislation and placed in a Hungarian remedial school. ${ }^{220}$ The Court ultimately found in the children's favor and reiterated the importance of the ability to make findings of indirect discrimination, particularly in the absence of discriminatory intent. ${ }^{221}$ The Court was particularly concerned about the methodology of IQ testing in the case and found there was a danger that the tests were culturally biased. ${ }^{222}$ Since the Hungarian legislation had a disproportionately prejudicial effect on Roma and there were inadequate protections in place to prevent the misdiagnosis and misplacement of Roma applicants, the Court held that the applicants suffered from discriminatory treatment. ${ }^{223}$ Ultimately, the Court's legal analysis reinforced the lines of reasoning developed in D.H. and Others and subsequent cases.

216. Oršuš and Others v. Croatia, App. No. 15766/03 Eur. Ct. H.R. (Mar. 16, 2010), đ 60 [hereinafter Oršuš and Others, Grand Chamber Judgment] (citing the Constitutional Court dismissal).

217. Oršuš and Others v. Croatia, App. No. 15766/03 Eur. Ct. H.R. (July 17, 2008), ๆ 65 [hereinafter Oršuš and Others, Judgment].

218. Id. \I 66 .

219. Oršuš and Others, Grand Chamber Judgment, supra note 216, đII 152-53.

220. Horváth and Kiss v. Hungary, App. No. 11146/11 Eur. Ct. H.R. (Jan. 29, 2013), II 6 [hereinafter Horváth and Kiss, Judgment].

221. Id. II 105.

222. Id. II 121.

223. Id. II 128. 
In many ways, the ECtHR has been instrumental in promoting substantive equality, particularly with regards to the educational segregation of Roma children. ${ }^{24}$ The ECtHR in Horváth and Kiss went beyond the Council of Europe, and required positive action to end discrimination and to account for structural deficiencies faced by groups historically affected by discrimination. $^{225}$ However, the ECtHR's jurisprudence has several weaknesses. In its jurisprudence surrounding Article 14 of the European Convention on Human Rights and its prohibition of discrimination, cases of direct as well as indirect discrimination can be objectively justified. ${ }^{226}$ This contrasts with the Race Equality Directive, which only allows for the justification of indirect discrimination. The distinction between direct and indirect discrimination has also remained unclear in ECtHR jurisprudence, which is particularly problematic due to the cross-citations between the CJEU and ECtHR. ${ }^{227}$ Inconsistencies in the application of standards and in the interpretation of indirect as compared to direct discrimination only undermine the great strides the ECtHR has made in addressing issues of school segregation.

Despite its lack of enforcement power, the ECtHR has a role to play in ending the segregation of Roma children. The nature of ECtHR decisions, as judgments of a human rights court, are well-suited to clarifying the legal aspects surrounding discrimination. ECtHR judgments are relatively long, detailed, and provide much more insight into the judicial decision making process than similar judgments by the CJEU. The CJEU has often referenced the ECtHR's jurisprudence in its judgments; although recently such references have diminished. ${ }^{228}$ Alone, the ECtHR is incapable of effecting change, but its judgments can have considerable impact when combined with the tools available to the European Commission and the CJEU to enforce compliance with anti-discrimination laws. The key issue is whether the EU organs wish to enforce compliance with these judgments. The European Union has historically given deference to Member States in implementing final judgments of the ECtHR. ${ }^{229}$ Given the ECtHR's unwillingness to impose substantive relief measures, the European Union must become more involved for the ECtHR's judgments to have any meaningful effect.

224. Van den Bogaert, supra note 213, at 727.

225. See Horváth and Kiss, Judgment, supra note 220, I[ 116 ("[T]he Court considers that the State has specific positive obligations to avoid the perpetuation of past discrimination or discriminative practices disguised in allegedly neutral tests.").

226. Van den Bogaert, supra note 213, at 723.

227. See id. at 723 .

228. De Búrca, supra note 196, at 173-74.

229. Greenberg, supra note 40, at 945. 


\section{E. National Anti-Discrimination Measures: The Case of Hungary}

Discrimination against the Roma primarily occurs at the national level. Hungary's methods of addressing cases of discrimination brought before its courts may prove particularly instructive. The national anti-discrimination laws of EU Member States, which transpose the provisions of EU antidiscrimination laws - including the Race Equality Directive - into national law, must fulfill the requirements of the Directive or else the Member State may face proceedings under Articles 226, 228 or 258 of the TFEU for failure to fulfill its treaty obligations. ${ }^{230}$ The laws of each EU Member State are therefore ostensibly compliant with the requirements of the Race Equality Directive. In terms of implementation, however, national courts must ensure that national laws are properly enforced. As such, implementation of the Directive often varies according to the requirements and peculiarities of Member States' domestic legal systems. ${ }^{231}$

In most Central and Eastern European countries, transposition of the Race Equality Directive into national law has not resulted in a substantial body of jurisprudence at the national level; few cases have arisen under the Directive. Hungary provides an important exception to this trend. As part of its accession process, Hungary enacted new anti-discrimination legislation in December 2003 and transposed the Race Equality Directive into Hungarian law. ${ }^{232}$ Subsequently, a number of cases were brought before Hungarian courts challenging the segregation of Roma children.

Even before the enactment of Hungary's anti-discrimination legislation, a Hungarian municipal court ruled against a segregated primary school in a 1998 decision. ${ }^{233}$ The case was brought by fourteen Roma students with the assistance of the Foundation for Romani Civil Rights, a Hungarian NGO. The students brought suit after a Hungarian periodical published a 1997 article describing how the Ferenc Pethe Primary School in the Hungarian town of Tiszavasvári had held separate graduation ceremonies for its Roma

230. TFEU arts. 226, 228, and 258. Article 226 of TFEU allows the European Parliament to investigate failures to implement EU law, if requested by a quarter of its Members. Article 228 involves investigation by the Ombudsman. Article 258 provides for an infringement proceeding to be brought by the Commission, with the potential for the infringement proceeding to go before the CJEU.

231. See Joint Report on the Application of Council Directive 2000/43/EC of 29 June 2000 Implementing the Principle of Equal Treatment Between Persons Irrespective of Racial or

Ethnic Origin ('Racial Equality Directive') and of Council Directive 2000/78/EC of 27 November 2000 Establishing a General Framework for Equal Treatment in Employment and Occupation ('Employment Equality Directive'), COM (2014) 2 final, at 4-8 (Jan. 17, 2014).

232. Farkas, supra note 23, at 335.

233. Hungarian Court Rules Against Segregation, EuROPEAN RoMA Rights CENTRE (Jan. 5, 1999), http://www.errc.org/article/hungarian-court-rules-against-segregation/2026 [https://perma.cc/UDJ5-T42 $\mathrm{E}]$. 
and non-Roma students. ${ }^{234}$ This was the first legal challenge in Central and Eastern Europe to segregation. ${ }^{235}$ The case progressed through the Hungarian court system, with the Roma students' claims succeeding at each stage. The Hungarian Supreme Court ultimately found violations of the Constitution and several education and minority-related laws. ${ }^{236}$ Similarly, in a 2007 case, the Debrecen Appeals Court in eastern Hungary overruled a lower court decision, and found that the Hungarian city of Miskolc had continued the segregation of Roma students in violation of the Race Equality Directive by integrating seven schools without redrawing catchment areas. ${ }^{237}$ The case was successfully litigated by the Chance for Children Foundation, a Hungarian NGO.

Most recently, however, the Hungarian Supreme Court overturned a lower court judgment in April 2015 and upheld the legality of an all-Roma school run by the Greek Catholic church. The Court held that the right to religious freedom superseded the prohibition of segregation and found that parents had freely selected the school and thereby exercised their freedom of religion. ${ }^{238}$ The primary school, located in a primarily Roma neighborhood in the Hungarian town of Nyíregyháza, was originally closed in 2007 in an effort to desegregate the school system, resulting in students being bussed to other schools in the city. ${ }^{239}$ As a result of strong opposition to desegregation from the white majority community, however, the school was reopened in 2011 by the ruling government, which placed it in the hands of the Greek Catholic church. In 2014, a lower court found that the reopened school violated both Hungarian law on equal opportunity and recommendations of the Council of Europe. ${ }^{240}$ The court subsequently ordered the school to stop

234. Roma Sue School in Northeastern Hungary: The Submission Against the Principal of the Ference Pethe Primary School, Tiszavasvári, Hungary, EuROPEAN Roma Rights CENTRE (May 15, 1998), http://www.errc.org/article/roma-sue-school-in-northeastern-hungary-the-submission-against-the -principalof-the-ferenc-pethe-primary-school-tiszavasvari-hungary/1807 [https://perma.cc/8T6X-YP7 T].

235. Open Soc'y Justice Initiative, Strategic Litigation Impacts: Roma School DESEGREGATION 21 (2016), https://www.opensocietyfoundations.org/sites/default/files/strategic-litigati on-impacts-roma-school-desegration-20160407.pdf [https://perma.cc/5HW7-ZP3J].

236. O'NiONS, supra note 6, at 156-57.

237. Legal Victory in Hungarian Roma School Segregation Case, EUROPEAN ROMA RigHTS CENTRE (May 18, 2007), http://www.errc.org/article/legal-victory-in-hungarian-roma-school-segregatio n-case/2777 [https://perma.cc/68SP-B9DM].

238. Eszter Neuberger, Hungary's Highest Court Legitimizes Segregation in the Case of Religious Schooling, THE BUDAPEST BEACON (Apr. 23, 2015), http://budapestbeacon.com/public-policy/hungaryshighest-court-legitimizes-segregation-in-the-case-of-religious-schooling/22387 [https://perma.cc/LL6PZRLP].

239. Nick Thorpe, Hungary Court Orders School Closure over Roma Segregation, BBC NEWS (Feb. 28, 2014), http://www.bbc.com/news/world-europe-26390357 [https://perma.cc/GT3A-9PUF].

240. Id. 
admitting new students. ${ }^{241}$ The same church ran a new school in the center of the city with much better amenities. When asked by the judge during the hearing if the Roma students could be accommodated in the newer, larger school, one of the priests replied that perhaps they could make room in the attic. ${ }^{242}$ One of the issues with the reopening of the school was that in the absence of free buses to take children to other schools, the cost of public transportation effectively limited the options of Roma children in that neighborhood to the school in question, thus casting doubt on the legitimacy of the freedom of choice argument embraced by the Supreme Court. ${ }^{243}$ This decision marked a blow for desegregation in Hungary.

One primary obstacle facing NGOs that wish to bring cases challenging rights violations is the task of finding plaintiffs willing to subject themselves to lengthy and intrusive legal processes. The Chance For Children Foundation has litigated the majority of Hungary's school segregation cases and has worked together on numerous matters with the European Roma Rights Centre - the leading public interest legal organization handling Roma rights in Europe. The key tool used by the Chance For Children Foundation is its ability under the Hungarian Constitution to bring an actio popularis in the interest of public order. This designation ultimately allows NGOs to bring cases without the need to provide specific plaintiffs. Several of the Foundation's key cases before Hungarian courts were brought in this manner. The larger volume of cases involving Roma discrimination brought before Hungarian courts - as compared to lesser volumes in other Central and Eastern European countries - is attributable, at least in part, to the existence of actio popularis under Hungarian law. However, the controversial 2011 revision to the Hungarian Constitution restricted actio popularis and limited the ability of NGOs to appeal cases advocating for Roma rights in the absence of affected plaintiffs. ${ }^{244}$ In 2013, the Hungarian Constitutional Court ruled that only natural and legal persons with a direct interest in an actual case could file a constitutional complaint against a court

241. Id.

242. Jeneen Interlandi, The Brain's Empathy Gap, N.Y. TimES MAG. (Mar. 19, 2015), http://www.nytimes.com/2015/03/22/magazine/the-brains-empathy-gap.html?_r=0 [https://perma.cc/YZ 3F-WSR3].

243. See The Nyíregyháza Resegregation Case, CHANCE FOR CHILDREN FOUNDATION (2015), http://www.cfcf.hu/en/ny\%C3\%ADregyh\%C3\%A1za-resegregation-case [https://perma.cc/ZR78-JYV 9].

244. See Katalin Kelemen, Access to Constitutional Justice in the New Hungarian Constitutional Framework: Life after the Actio Popularis?, in LAW, POLITICS, AND THE CONSTITUTION: NEW Perspectives from Legal and Political Theory 63, 65 (Antonia Geisler, Michael Hein \& Siri Hummel eds., 2014). 
decision. ${ }^{245}$ This effectively undermined the constitutional protection against discriminatory practices. ${ }^{246}$

Facially, the European Union appears to offer a variety of protections against discrimination, with directives pertaining to gender, ${ }^{247}$ race $^{248}$ and disability, ${ }^{249}$ among others. However, despite a gradual shift toward upholding fundamental rights, the European Union remains primarily focused on market access. Ultimately, even where the mandate is ostensibly broader, such as with the Race Equality Directive, anti-discrimination measures are primarily invoked to facilitate employment and commerce, and not to address systemic racism. While the European Union's directives contain within them the seeds of genuine anti-discriminatory potential, they are inadequate as practically implemented to remedy non-economic-based racism.

In everyday life, visible minorities in Europe continue to experience routine acts of 'petty racism' which, as Möschel notes, "are judicially trivialised and dismissed or interpreted as reactions of over-sensitive individuals." ${ }^{250}$ Ultimately, both the Race Equality Directive and national anti-discrimination laws as currently implemented reflect a focus on the perpetrator perspective rather than the victim perspective, as the condition of victims is considered of lesser importance than the elimination of identified violations. $^{251}$ This emphasis is unsurprising, since critical race theory predicts such a result in systems like those in the United States and the European Union.

\section{THE PATH FORWARD - SUGGESTIONS FOR A MORE EFFECTIVE MEANS OF ADDRESSING ROMA SEGREGATION IN EUROPE}

Discrimination against the Roma is widespread throughout Europe. Europeans who would likely be appalled by racist language targeting Asians and Africans will casually use pejorative terms when talking about Roma.

245. András Kádár, Constitutional Court Denies Legal Standing of NGO's in Actio Popularis Cases, EUROPEAN EQUALITY LAW NETWORK (Jan. 14, 2014), http://www.equalitylaw.eu/component/edocman/ ?task=document.viewdoc\&id=1588\&Itemid [https://perma.cc/44F3-79XW] (citing the Hungarian Constitutional Court decision no. IV/03311/2012 (delivered on June 17, 2013)).

246. Id.

247. Gender Equality Directive, supra note 138.

248. Race Equality Directive, supra note 120.

249. Council Directive 2000/78/EC of 27 November 2000 Establishing a General Framework for Equal Treatment in Employment and Occupation, 2000 O.J. (L 303) 16.

250. MösCHEL, supra note 49, at 135.

251. See id. at 137. 
As the Roma rights scholar and activist James Goldston notes, "[t]he stereotypes about Gypsies are so insidious that even some leading human rights activists share the tendency to minimize the extent of Roma mistreatment, to react defensively when their national governments are criticized for their Roma policies, or to blame the Roma for their own troubles." ${ }^{\prime 252}$ While Europe's climate of casual racism makes the struggle for equality more challenging than it might be otherwise, it does not mean that there are no steps that can be taken toward eliminating the segregation of Roma children. In this section, I propose three measures with the potential to address the inadequacies and ineffectiveness of the current legal regime. The following suggestions do not offer an absolute remedy, nor are they guaranteed to be effective. However, taken together, they have potential to counter some of the systemic forces hindering desegregation. The three suggestions that follow represent a combination of approaches-namely, a top-down approach; a bottom-up approach; and external international pressure.

The first suggestion emphasizes a bottom-up approach to addressing segregation. At the grassroots level, lawyers must bring more legal challenges to school segregation before national courts throughout Central and Eastern Europe. While Hungary has demonstrated success with public interest impact litigation, too few lawyers are involved in this type of work and far too few challenges have been brought before national courts. Without cases initiated before national courts, the potential for social transformation will remain limited; particularly where political action and policies aimed at social change have been ineffective. Without active litigation by grassroots organizations and domestic lawyers, the CJEU and the European Commission remain handcuffed in their ability to effect social change. Even if cases are dismissed by national courts, the mere act of bringing them can garner national and international attention; as has been the case with school segregation cases. Active grassroots involvement of attorneys and NGOs is arguably the most important element to the elimination of school segregation against the Roma.

There are challenges to a grassroots approach. James Goldston argues that rather than demonstrating that law can be a tool for reform, one effect of repeated situations where landmark Roma rights decisions lead to continued segregation and police abuse "may be to devalue law by revealing its powerlessness." 253 This argument underestimates the power of litigation as

252. James A. Goldston, Roma Rights, Roma Wrongs, in EASTERN EUROPEAN ROMA IN THE EU: Mobility, Discrimination, Solutions 14, 14 (Anca Pusca ed., 2012).

253. Goldston, supra note 22, at 312 . 
an instrument of gradual change and ignores the success that impact litigation has had in the United States under similar circumstances in bringing awareness to ongoing issues of discrimination. There are certainly barriers to public interest litigation that must be overcome, ${ }^{254}$ and the outcome of litigation may not result in immediate change. Yet public interest litigation arguably represents the most powerful tool for achieving equality between Roma and non-Roma. By using individual cases to bring attention to the systemic issues and to the general situation of Roma children, impact litigation can exert broad influence on social policy. In support of a grassroots approach, Goldston notes that process-based arguments have been particularly successful, as have cases built around evidence of systemic problems. ${ }^{255}$

Organizations like the European Roma Rights Centre and the Hungarian Chance for Children Foundation have proven instrumental in bringing cases of anti-Roma discrimination before national courts. One challenge such organizations face is finding plaintiffs willing to litigate their claims; particularly given Roma mistrust of the legal system and of government generally. Most European litigators who accept Roma rights cases are non-Roma, since few Roma are sufficiently enfranchised to hold law degrees. Given that the issue at hand involves school segregation, it is unsurprising that decades of Roma segregation have resulted in there being far fewer Roma lawyers than necessary to create a Roma-driven grassroots impact litigation movement. As part of the effort to increase Roma participation in education, activists should emphasize the importance of lawyers and the legal profession in promoting change. High profile instances of impact litigation may help shift Roma perceptions and assuage fears concerning involvement with national court systems.

In the United States, impact litigation has played an important role in advancing civil rights. It has provided minorities a voice in the legal process where they would otherwise have remained silenced. Even where unsuccessful, many cases brought across the United States-particularly in the South - attracted public attention, influenced public discourse, and cast issues of segregation into the national spotlight.

The second suggestion is for greater involvement by the CJEU and the European Commission in ensuring that the provisions of the Race Equality Directive are enforced. Legislative measures will only prove effective if those responsible for implementing such measures cooperate, and such cooperation is unlikely to occur voluntarily. Without a strong 'federal'

254. See id. at 317 (laying out the barriers to effective public interest litigation).

255. Id. at $317,320,321-22,323$. 
government to impose top-down measures, the Central European countries, which resemble the Alabamas and Mississippis of the 1950s and 60s in their discrimination against Roma, have little incentive to enforce antidiscrimination policies. In much the same way that the United States Supreme Court was instrumental in forcing desegregation upon the southern states, so too can the CJEU act as a force in condemning continued segregation. This top-down approach brings the weight of the European Union to bear on national courts and governments. While critical race theory demonstrates that a top-down approach cannot fully eliminate discrimination and lacks the capacity to change systems that promote discrimination, topdown forces are vital in overcoming intransigence at the national level. Without top-down pressure, Central and Eastern European countries will lack the motivation necessary to enact real, impactful changes.

As more cases involving the Race Equality Directive are brought before the court, the CJEU may be more willing to directly address issues of race and ethnicity. As CHEZ RB illustrated, the CJEU is open to inclusive interpretations of discrimination. How the CJEU's jurisprudence develops its interpretation in future segregation cases remains to be seen, but there are avenues of possibility for the CJEU. Legal scholars have also begun to discuss race in Europe more specifically, and not as part of an abstract and detached idea of discrimination. These discussions may shift in a positive direction conversations of policy concerning the Roma.

While the European Union, through infringement proceedings, can hold Member States accountable for failures to uphold anti-discrimination laws, it lacks the power to prescribe what Member States can or cannot do with regards to education. In creating a quasi-federal entity, the European Union and the United States face similar difficulties in the realm of education; for instance, the idea of a national curriculum has been widely opposed in the United States for decades. It remains to be seen if the proceedings initiated by the European Commission against the Czech Republic and Slovakia will result in CJEU cases, and if so, whether the CJEU will adopt an interpretation of indirect discrimination that prevents countries from bypassing legal mandates by modifying their educational policies in manner that entrenches educational segregation.

Although DH and Others was a seminal ECtHR case, subsequent actions by the Czech Republic indicate that without further litigation and substantive penalties imposed by the European Union, countries such as the Czech Republic will resist efforts to integrate their schools - much like the Southern states during the Civil Rights Movement. Until now, almost all decisions condemning discrimination against the Roma have come from the ECtHR or from national courts. As Jack Greenberg notes, "[e]ven as courts 
find for the Roma plaintiffs, they fail to enforce effective remedies against the offending schools." ${ }^{256}$ In this respect, perhaps the CJEU may have greater capacity to effect change, although it would be naïve to think that the Court can offer a panacea for Europe's race issues, given its traditional market access-focused approach to rights. Critical race theory also suggests that even if the CJEU successfully forced desegregation upon EU Member States, its efforts would likely be undermined by continuing racism and subsequent interest divergence - as seen in the United States post-Brown. Nevertheless, the CJEU will remain instrumental in the continued development and enforcement of EU anti-discrimination law, and it is imperative that a Brown-type decision emerge not only from the ECtHR, but also from the CJEU, which holds greater legal influence over EU Member States.

Some may argue that with EU Member States increasingly skeptical of European Union involvement in their national affairs, it is an inopportune time to advocate for greater European Union involvement in issues of discrimination and social injustice. However, if such involvement does not occur, the European Union will remain a fragmented body where some Member States take their obligations more seriously than others. A slippery slope exists between selective enforcement of human rights and widespread selectivity in the enforcement of other fundamental freedoms that relate to the very origins of the European Union. The CJEU and the European Commission are essential to the fight against discrimination and segregation in Europe.

Finally, the third and complementary suggestion is to attract greater international attention to the plight of the Roma. Heightened global awareness will force the European Union and its Member States to respond to international criticism. International pressure played a role in forcing the United States Government to address segregation in the $1950 \mathrm{~s}$ and $60 \mathrm{~s},{ }^{257}$ and similar pressure can be brought to bear against Europe. The United Nations has acknowledged the discrimination facing the Roma, but has stopped short of condemning European inaction. The United States maintained observer status as part of the Decade of Roma Inclusion, suggesting that it has an interest in the effective resolution of Roma discrimination. Now, the United States must take action to advocate aggressively for the elimination of segregation and the removal of barriers to Roma integration throughout Europe. Ultimately, the United States has an opportunity, at a time when it is facing its own significant challenges with

256. Greenberg, supra note 40, at 938 .

257. See generally, e.g., Azza Salama Layton, International Pressure and the U.S. Government's Response to Little Rock, 66 ARK. HIST. Q. 243 (2007). 
racial issues, to demonstrate a commitment to racial equality, both at home and abroad. Only by upholding principles of equality and justice for all can the international community continue to improve global human rights.

In a time when countries increasingly eschew global human rights in favor of domestic isolationist concerns, it is particularly imperative that supposed beacons of freedom and democracy be held to task for their failings. This applies to Europe as much as to the United States, and the treatment of the Roma is illustrative of Europe's failure to adhere to the values that EU Member States have supposedly committed to uphold. Now, more than ever, the international community must pressure the European Union to take action to eliminate segregation.

These are by no means easy fixes, and a great deal of individual effort and political will is required for these measures to be successful. In today's political climate, the fight to end Roma discrimination will likely be an uphill battle with no simple solution. Acknowledging the role that race plays and the need for legal measures that provide race-based protections is an important starting point. The key is to recognize that participation across all jurisprudential levels is necessary for success, and for systemic changes to occur, bottom-up impact litigation must drive top-down enforcement of existing rules that so far have been sporadically implemented and enforced.

\section{CONCLUSION}

For Europe to advance as a society, the Roma must achieve justice and equality. That such a large minority has suffered from discrimination for so long in one of the most developed and supposedly enlightened parts of the world without significant backlash from the international community beggars belief. With every generation of children that continues to suffer school segregation, discriminatory attitudes toward the Roma become further entrenched and opportunities for inclusion of the Roma in European society slip increasingly out of reach.

Critical race theory helps explain why legislative and policy initiatives have yet to eliminate the segregation of Roma children in schools, despite the comprehensive nature of existing legal protections. So long as white majorities in EU Member States - and particularly those in Central Europerefuse to accept desegregation, ensuring proper enforcement of the Roma's legal rights will remain an uphill battle. Impact litigation is perhaps the most important component of the fight against segregation in Europe. Such litigation increases international awareness of matters involving social injustice - even where national governments would rather brush them under the rug. Impact litigation can also lead to infringement proceedings initiated by the European Union and significant penalties can be levied if the 
enforcement of anti-discrimination laws continues to be lax. Increased international scrutiny may also attract localized funding to assist NGOs in driving impact litigation.

In light of today's political climate, it would be overly optimistic to believe that systemic change is likely to occur in the next few years. However, if the Civil Rights Movement had given up in light of its failures in the United States, legalized segregation would likely still persist in the United States. Until Europe recognizes Roma equality - both substantively and legally-it will lack credibility as a leader among the international human rights community. In this respect, Roma children must not only be integrated into white majority schools, but white majorities must also be educated about Roma equality. Only through education will the hearts and minds of white majority Europeans be changed. 